\title{
A review of Erotinae and Dictyopterinae (Coleoptera: Lycidae), with description of new taxa and a note on biogeography of the subfamilies
}

\section{Обзор Erotinae и Dictyopterinae (Coleoptera: Lycidae), с описанием новых таксонов и замечанием по биогеографии подсемейств}

\author{
Sergey V. Kazantsev \\ C.В.Казанцев
}

Insect Centre, Donetskaya 13-326, Moscow 109651, Russia.

Инсект-центр, ул. Донецкая 13-326, Москва 109651, Россия. E-mail: kazantss@mail.ru

KEY WORDS: Coleoptera, Lycidae, new tribes, new genus, new species, taxonomy.

КЛЮЧЕВЫЕ СЛОВА: Coleoptera, Lycidae, новые трибы, новый род, новые виды, таксономия.

ABSTRACT. The subfamilies Erotinae and Dictyopterinae are reviewed. Three new tribes, Lopherotini tr.n., Proterotaphini tr.n. and Macrolycinellini tr.n., and a new subtribe, Pseudaplatopterina, subtr.n., are established. A new genus, Platycides gen.n., and seven new species are described: Platycides holzschuhi, Taphomimus huaphanensis, Dictyoptera phoupanensis, D. panicola, D. laomontana, D. recticarinata (Laos) and D. triachroma (Vietnam), spp.n. Dictyoptera bicoloricornis (Pic, 1933), syn.n. is put in synonymy with D. quadricostata (Pic, 1927). Coloberos incisus (Pic, 1925), comb.n., C. pahanganus (Kleine, 1939), comb.n., C. malaccanus (Pic, 1922), comb.n. and C. klossi (Blaire, 1928), comb.n. are transferred to Coloberos Bourgeois, 1885 from Pyropterus Mulsant, 1838. The aedeagus of Dictyoptera laosensis (Pic, 1926) is illustrated. A checklist of Erotinae and Dictyopterinae is provided, as well as a note on their biogeography.

РЕЗЮМЕ. Приводится обзор подсемейств Erotinae and Dictyopterinae. Устанавливаются три новые трибы, Lopherotini tr.n., Proterotaphini tr.n. и Macrolycinellini tr.n., а также новая подтриба, Pseudaplatopterina, subtr.n. Описывается новый род, Platycides gen.n., и семь новых видов: Platycides holzschuhi, Taphomimus huaphanensis, Dictyoptera phoupanensis, D. panicola, D. laomontana, D. recticarinata (Лаос) и D. triachroma (Вьетнам), spp.n. Dictyoptera bicoloricornis (Pic, 1933), syn.n. сводится в синонимы к D. quadricostata (Pic, 1927). Coloberos incisus (Pic, 1925), comb.n., C. pahanganus (Kleine, 1939), comb.n., C. malaccanus (Pic, 1922), comb.n. и C. klossi (Blaire, 1928), comb.n. переносятся в Coloberos Bourgeois, 1885 из Pyropterus Mulsant, 1838. Приводятся иллюстрации эдеагуса Dictyoptera laosensis (Pic, 1926). Приводится список и краткий обзор биогеографии Erotinae и Dictyopterinae.

\section{Introduction}

The erotine and dictyopterine lineages of net-winged beetles have traditionally been treated together, either as Erotinae [e.g., LeConte, 1881; Miller, 2002] or Dictyopterinae [e.g., Kleine, 1929, 1933], despite the evident difference in their pronotal structure, possibly because of the similarity of their filiform antennae, regularly reticulate elytra and, to some extent, aedeagal structure. When it was disclosed that there existed two names for the group, the younger Dictyopterinae was synonymized with Erotinae [Bocák \& Bocáková, 1990].

The validity of dictyopterines, however, was restored shortly afterwards [Kazantsev, 2004, 2006], after cladistic analyses of morphological characters of the two groups were carried out that revealed crucial differences in abdominal and genital structures between the two. In a more recent paper, with a molecular based classification of Lycidae, the independent status of both lineages was also confirmed [Bocák \& Bocáková, 2008] — although the authors' classification in general, which happens to be in deep conflict with the published data on morphology and biogeography of Lycidae [including their own, e.g. Bocák \& Bocáková, 1990], can hardly be accepted. Also, certain errors, such as defining position of the tribe Slipinskiini (type genus Aferos Kazantsev, 1991) on the basis of molecular data from the totally different Flagrax Kazantsev, 1991 (tribe Dictyopterini) does not add credibility to their conclusions. Nevertheless, it seems reasonable, pending a comprehensive revision of the classification of the family, to regard erotines and dictyopterines as independent lineages, although they still may prove to represent a larger single clade [as suggested in Kazantsev, 2012a].

The predominantly Holarctic Erotinae and Dictyopterinae have been receiving decent attention in recent years [e.g., Bocák \& Bocáková, 1991, 1999; Kazantsev, 
1990-2010; Matsuda, 2010], yet new taxa at different level are still being discovered.

A morphological analysis of these groups shows that three new tribes, Lopherotini tr.n., Proterotaphini tr.n. and Macrolycinellini tr.n., and a new subtribe, Pseudaplatopterina, subtr.n., have to be erected. Their descriptions, as well as certain taxonomic notes that were deemed necessary, and descriptions of a new erotine genus and several new dictyopterine species are presented below.

\section{Material and methods}

Specimens used as material for this study were dissected after being softened in water, with the genitalia extracted, cleared for several hours in $10 \% \mathrm{KOH}$ at room temperature, then placed in microvials with glycerine. MSP-1 zoom stereoscopic dissecting microscope with $x 8-x 80$ magnification range was used.

The following acronyms are used in the paper:

ICCM - Insect Center Collection, Moscow;

MNHN_-Muséum national d'Histoire naturelle, Paris.

\section{Taxonomy}

\section{Erotinae Leconte, 1881}

Type genus: Eros Newman, 1838

DIAGNOSIS. Erotinae may be distinguished from other lycids by a combination of seven-areole pronotum, with two antero-median areoles, two antero-lateral areoles, two postero-lateral areoles and a postero-median areole (Fig. 1), well developed and more or less regular reticulation between elytral costae, elongate parameral tube and little modified median lobe of the aedeagus (Figs 3-4, 7), long speculum gastrale with long lateral arms (Fig. 5) and very long free valvifers of the external female genitalia (Fig. 6).

DISTRIBUTION. Erotinae includes two tribes, Erotini and Lopherotini tr.n., distributed in the Holarctic in isolated pockets on its periphery, somewhat expanding into the extreme north-east of the Oriental zone (Map 9).

REMARKS. Erotinae may be easily differentiated by a combination of unique apomorphies, the seven-areole pronotum (Fig. 1) and long speculum gastrale with long lateral arms (Fig. 5), and apparently deserves an equal rank with Dictyopterinae. Lopherotini tr.n., which seems to be rather different from the nominative tribe, does not share all aforesaid apomorphies, however the structure of the pronotal carinae in one of its members, the fossil Protolopheros, Kazantsev, 2012, appears to be reminiscent of that of Erotini.

The oriental genus Microcoloberos Pic, 1913, which was referred to Erotini by Bocák \& Bocáková [2008] (who also misspelt it as Microcoleborus), as the study of the type suggests [Kazantsev, 1993], apparently does not belong in this lineage.

\section{Erotini Leconte, 1881}

Type genus: Eros Newman, 1838

DIAGNOSIS. Erotini may be easily differentiated from other erotines by the long speculum gastrale with long lateral arms (Fig. 5), very long free valvifers of the external female genitalia (Fig. 6) and elongate parameres of the aedeagus enveloping the median lobe (Figs 3-4).
DISTRIBUTION. Erotini includes two subtribes, Erotina Leconte, 1881 and Pseudaplatopterina subtr.n. The distribution area of the tribe lies in the Holarctic, represented by isolated patches on its periphery (Maps 1-2).

\section{Erotina Leconte, 1881}

Type genus: Eros Newman, 1838.

DIAGNOSIS. Erotina may be distinguished from Pseudaplatopterina subtr.n. by the combination of complete pronotal carinae, forming seven areoles (Fig. 1), long and rounded distally parameres of the aedeagus and widened proximally phallobase (Fig. 3).

DISTRIBUTION. Erotina includes four genera, Platycis Thomson, 1864, Erotides Waterhouse, 1879, Konoplatycis Nakane, 1969 and Platycides gen.n. The distribution area of the new subtribe lies in the Holarctic, represented by isolated patches on its periphery, also somewhat penetrating into the extreme north-east of the Oriental zone (Map 1).

\section{Platycides Kazantsev gen.n.}

Type species: Platycides holzschuhi Kazantsev gen.n.

DESCRIPTION. Alate, flattened, elongate. Head transverse, slightly narrowed behind eyes. Fastigium acute, ca. 70 , frontal process triangular. Eyes small, spherical. Labrum small, transverse, sclerotized, entirely overlapped by frons. Mandibles small, abruptly curved curved in the middle. Maxillary palps robust, 4-segmented, with ultimate palpomere elongate, elliptical, apically narrowed and flattened. Labium consisting of non-paired transverse mentum, nonpaired prementum and a pair of small 3-segmented palps; ultimate palpomere apically widened and flattened. Gula short. Antennal prominence conspicuous, with deep median impression; antennal sockets widely separated. Antenna 11segmented, long, almost attaining to elytral apices, filiform, with antennomere 2 small, considerably shorter than antennomere 3; antennomeres 3-11 with short dense sub-erect pubescence (Fig. 1).

Pronotum transverse, subrectangular, ca. 6 times shorter and noticeably narrower than elytra, with seven prominent areoles: two antero-median areoles separated by narrow median carina, two antero-lateral areoles, two postero-lateral areoles and postero-median areole in posterior third, open near posterior pronotal margin and bearing very narrow median carina (Fig. 1). Prosternum narrow, T-shaped, slightly emarginate anteriorly. Mesothoracic spiracles short. Mesoventrite transverse, anteriorly emarginate, without median suture; mesepimeron conspicuously shorter and narrower than mesepisternum. Mesonotum with scutellum not attaining to anterior margin, mesoscutal halves not divided; scutellum with relatively long postnotal plate, emarginate at apex. Elytra long, parallel-sided, with four primary costae; interstices with one row of regular, mostly transverse cells; bottom of cells glabrous; pubescence distributed along longitudinal and transverse costae. Metanotum transverse, widening anteriorly, with almost straight scuto-scutellar ridge, somewhat shorter than allocrista; prescutum with complete median rib; intrascutal suture emerging from mid-allocrista; scutellum straight posteriorly, with median suture; postnotal plate transverse, medially elongated, without median suture. Metaventrite about as long as wide, with blunt posterior angles; discrimen (metasternal suture) complete. Metathoracic wing with elongate anal and wedge cells; wedge cell closed with perpendicular vein; $\mathrm{Cu}$ veins merged to $\mathrm{M}$; cu-a brace connecting $\mathrm{Cu}_{2}$ and $\mathrm{A}_{1}$ slightly below $\mathrm{Cu}$ veins branching point.

Pro- and mesotrochantins subequal in width. Pro- and mesocoxae transverse; metacoxae narrowly separated, placed 

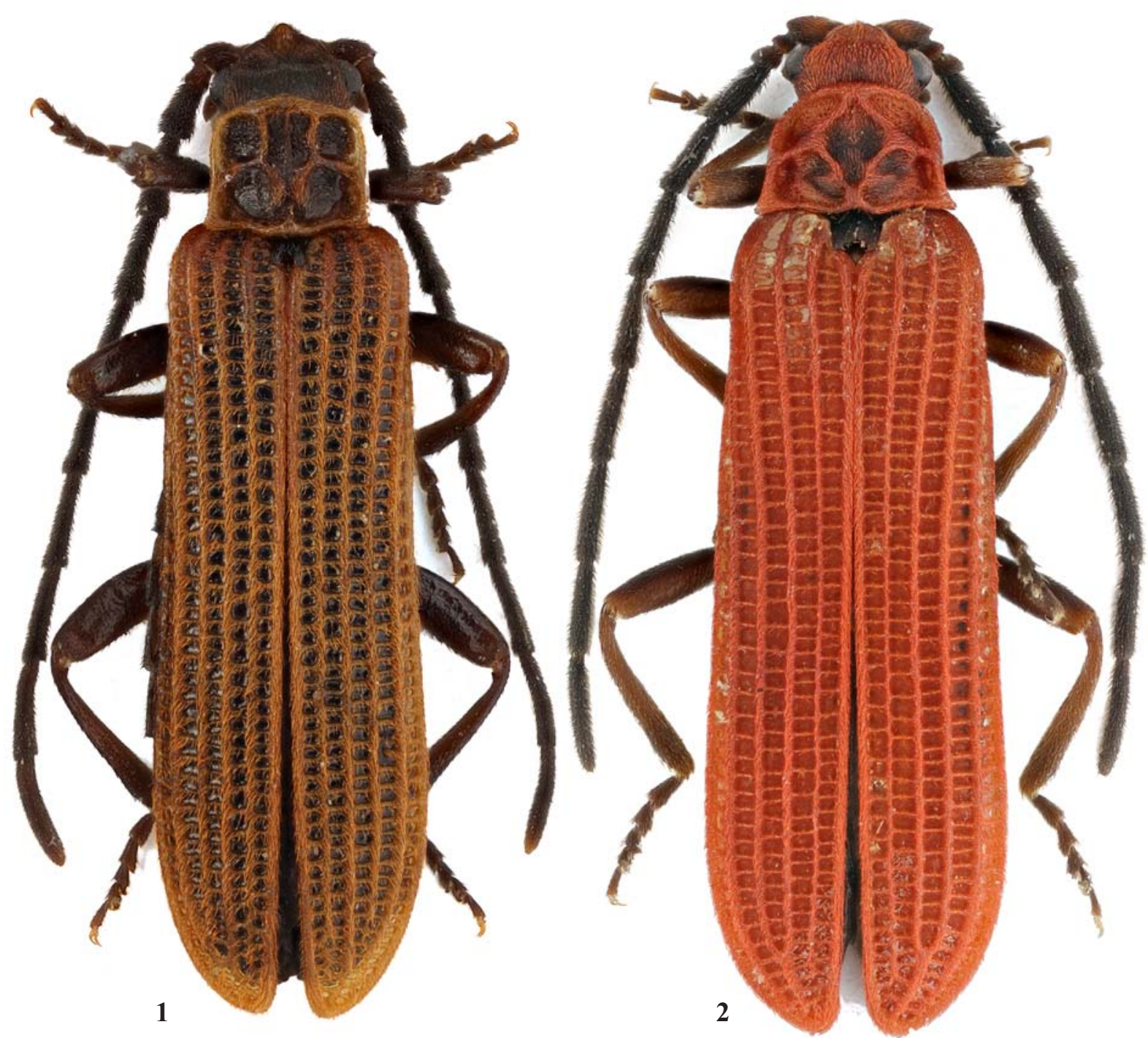

Figs 1-2. General view of Erotinae and Dictyopterinae: 1 - Platycides holzschuhi gen.n., sp.n.; 2 - Taphomimus huaphanensis sp.n.; $1-2$ - holotype males.

Рис. 1-2. Общий вид Erotinae и Dictyopterinae: 1 - Platycides holzschuhi gen.n., sp.n.; 2 - Taphomimus huaphanensis sp.n.; 1 2 - голотипы, самцы.

at ca. $135^{\circ}$. Pro- and mesotrochanters subequal in size; metatrochanters somewhat larger. Legs moderately long and narrow; trochanters slightly triangular, connected to femora distally; tibiae slightly curved, tibial spurs narrow, but well noticeable; tarsomeres 1-4 narrow, with distal plantar pads; all claws simple. Abdominal spiracles dorsal, located on membrane, near edge of sternite.

Male. Pro-, meso- and metatrochanters with pilose cavity. Spiculum gastrale short and relatively broad, rounded at apex; penultimate tergite without median suture. Aedeagus symmetric, with long straight simple median lobe; elongate separate parameres enveloping median lobe almost as long as median lobe, without thorns; phallobase elongate, with noticeable lateral processes, without median suture (Figs 3-4).

Female. Terminal sternite with long, moderately long spiculum ventrale (Fig. 5). External genitalia with long free narrow valvifers, free sclerotized coxites and elongate styli (Fig. 6).
DIAGNOSIS. Platycides gen.n. appears to be allied to Erotides, namely, to the subgenus $E$. (Erotides) Waterhouse, 1879 , also with pilose cavities in male hind trochanters, differing by the triangular frontal process, longer third antennomere, only one row of cells between primary elytral costae (Fig. 1) and presence of pilose cavities in front and middle male trochanters as well. It differs from all erotine genera with the similar pronotal structure by the triangular frontal process, long third antennomere, one row of cells in elytral interstices (Fig. 1) and pilose cavities in all male trochanters.

\section{Platycides holzschuhi Kazantsev sp.n.}

Figs 1, 3-6

MATERIAL: Holotype, O $\bigcirc^{7}$ E Laos, Hua Phan prov., Ban Saleui, Phou Pan Mt., $20^{\circ} 12^{\prime} \mathrm{N}, 1^{\circ} 04^{\circ} \mathrm{E}, 1300-1900 \mathrm{~m}, 1-31 . V .2011$, C. Holzschuh leg. (ICCM); paratypes: $100^{\top} \mathrm{O}^{\top}, 8$ 8 , same label (ICCM).

DESCRIPTION. Male. Black. Pronotal and elytral ribs/ costae and margins brownish. 
Head dorsally finely punctate, antennal sockets elliptical, separated by ca. their vertical width. Eyes small (separated medially above by about 6 times their radius). Ultimate maxillary palpomere large, elongate, about twice long as wide. Antennae long, almost attaining elytral apices, filiform; antennomeres slightly widened distally; antennomere $3 \mathrm{ca}$ 2.5 times longer than antennomere 2 and 1.2 times shorter than antennomere 4 (Fig. 1).

Pronotum transverse, 1.3 times wider than long, with almost straight sides, conspicuous anterior and small acute posterior angles, anterior margin slightly convex (Fig. 1). Scutellum elongate, parallel-sided, emarginate at apex.

Elytra long (ca. 4 times as long as wide humerally), parallel-sided, with four primary costae, each reaching elytral apices; interstices with one row of regular, subquadrate or (mostly) transverse cells; bottom of cells glabrous, shining; pubescence short and decumbent.

Aedeagus with straight median lobe, slightly flattened and bent near apex; parameres only slightly shorter than median lobe; phallobase elongate, widened proximally (Figs 3-4).

Female. Similar to male, but antennae shorter.

Length: $6.8-9.2 \mathrm{~mm}$. Width (humerally): $1.8-2.0 \mathrm{~mm}$.

ETYMOLOGY. The new species is named after Carolus Holzschuh (Villach, Austria) who collected the type series.

DIAGNOSIS. Platycides holzschuhi sp.n. is easily distinguishable from other Erotini by the generic characters.

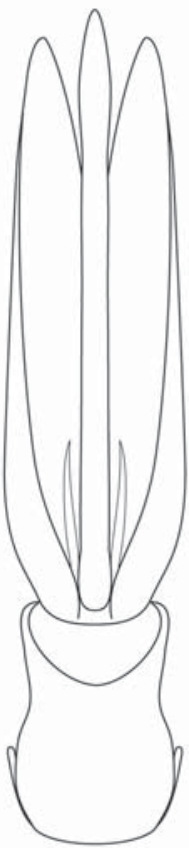

3

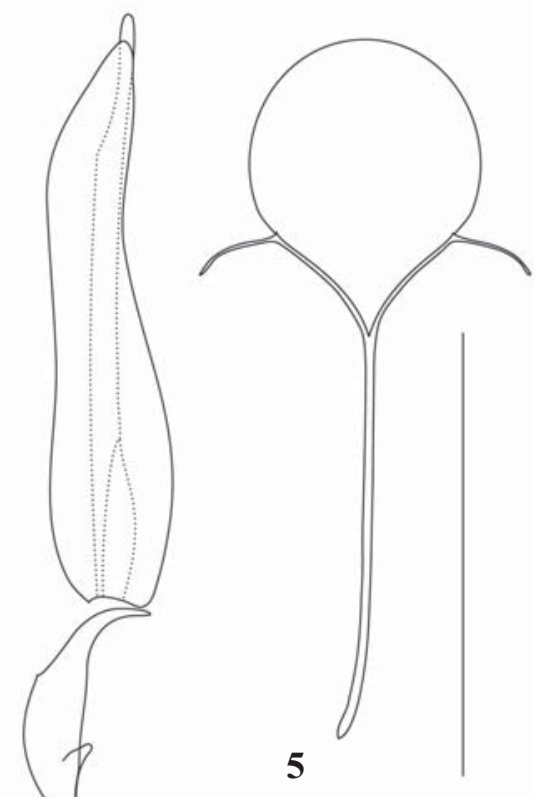

4

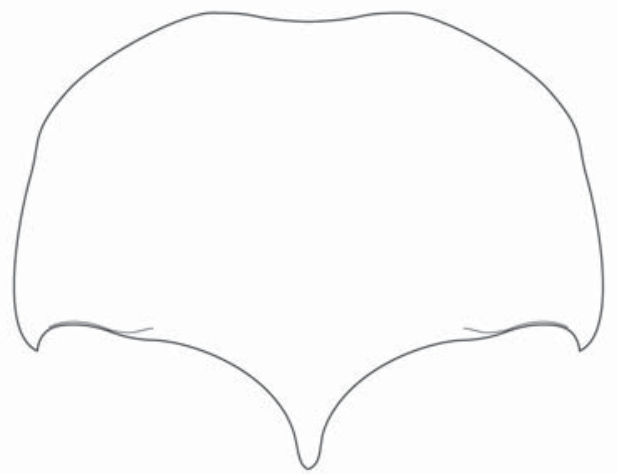

8

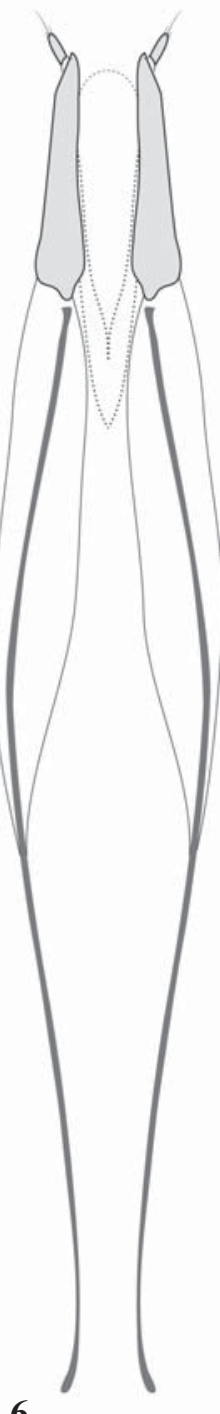

6

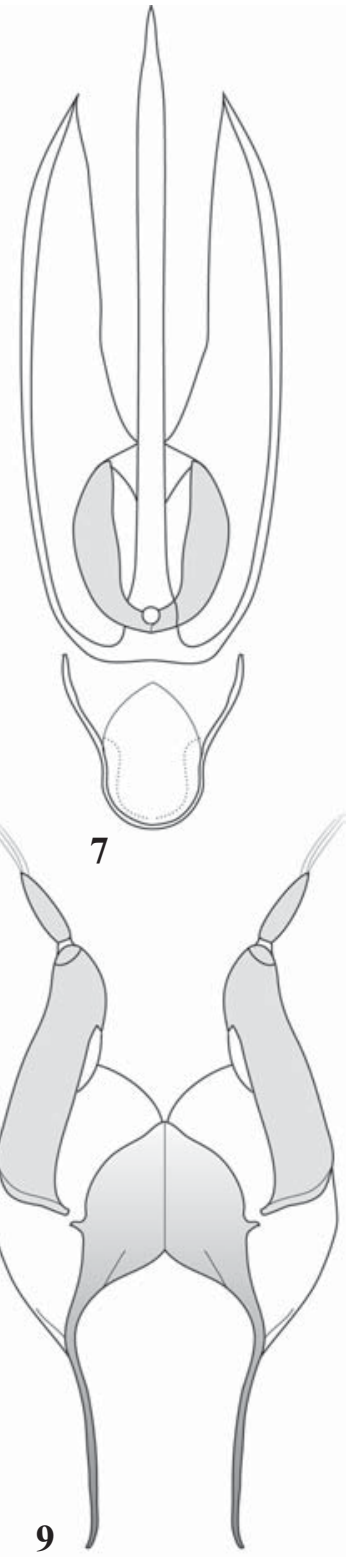

Figs 3-9. Details of Erotinae: 3-6 - Platycides holzschuhi gen.n., sp.n.; 7 - Pseudaplatopterus (Eropterus) glebulus; 8 Aplatopterus rubens; 9 - Eulopheros harmandi; 3-4, — aedeagus; 5, 8 - terminal sternite; 6, 9 - external genitalia; 3, 5-9 - dorsal view; 4 - lateral view; 3-4, - holotype males; 5-6 - paratype female. Scale bar: $5 \mathrm{~mm}$. [Figs 7-9 given after Kazantsev, 2004]

Рис. 3-9. Детали строения Erotinae: 3-6 - Platycides holzschuhi gen.n., sp.n.; 7 - Pseudaplatopterus (Eropterus) glebulus; 8 Aplatopterus rubens; 9 - Eulopheros harmandi; 3-4, — эдеагус; 5, 8- вершинный стернит; 6, 9 - наружные гениталии; 3, 5-9 сверху; 4 - сбоку; 3-4, — голотипы, самцы; 5-6 - паратип, самка. Масштабная линейка: 5 мм. [Рис. $7-9$ даны по Kazantsev, 2004] 
Pseudaplatopterina subtr.n.

Type genus: Pseudaplatopterus Kleine, 1940.

DIAGNOSIS. Pseudaplatopterina subtr.n. may be distinguished from Erotina by a combination of almost obsolete pronotal carinae, somewhat shortened and pointed distally parameres of the aedeagus and narrowed proximally phallobase (Fig. 7), hypothetically its apomorphies. The reduced pronotal carinae appear to be at the same time homoplastic with those of Lopherotini tr.n.

DISTRIBUTION. Pseudaplatopterina subtr.n. includes just one genus, Pseudaplatopterus Kleine, 1940. While one of its two subgenera, Pseudaplatopterus s.str., is known only from the Baltic amber, the other, Pseudaplatopterus (Eropterus) Green, 1951, is distributed in three isolated pockets on the periphery of the Holarctic (Map 2).

\section{Lopherotini Kazantsev tr.n.}

Type genus: Lopheros Leconte, 1881.

DIAGNOSIS. Lopherotini tr.n. may be distinguished from Erotini by a combination of the reduced longitudinal and transverse pronotal carinae and absence of pronotal areoles, absent speculum gastrale (Fig. 8), shortened parameres and widened distally median lobe of the aedeagus and short, sometimes fused to each other valvifers of the external female genitalia (Fig. 9), which are considered to be its apomorphies. A cladistic analysis [Kazantsev, 2010] demonstrates that including the Lopheroti taxa in Erotini renders the latter paraphyletic. The reduced pronotal carinae appear to be homoplastic with Pseudaplatopterina subtr.n.

DISTRIBUTION. Lopherotini tr.n. includes four genera, Lopheros Leconte, 1881, Aplatopterus Reitter, 1911, Eulopheros Kazantsev, 1995 and Protolopheros Kazantsev, 2012, the latter genus known only from the Baltic amber [Kazantsev, 2012b]. The distribution area of the new subtribe lies in the Holarctic, represented by several isolated patches on its periphery, also somewhat penetrating into the extreme north-east of the Oriental region (Map 3).

REMARKS. Lopherotini tr.n. seems to be rather different from Erotini, the nominative tribe of Erotinae. However, the structure of the pronotal carinae in one of its members, the fossil Protolopheros, Kazantsev, 2012, appears to be reminiscent of that of Erotini, with vestiges of carinae making up antero-median areoles [Kazantsev, 2012b]; therefore, Lopherotini tr.n. is classified in Erotinae.

\section{Dictyopterinae Houlbert, 1922}

Type genus: Dictyoptera Latreille, 1829

DIAGNOSIS. Dictyopterinae may be distinguished from other lycids, particularly from Erotinae, by a combination of the rhomboidal pronotal areole (modified in Macrolycinellini tr.n.) and well developed and more or less regular reticulation between elytral costae (Figs 2, 20-23).

DISTRIBUTION. Dictyopterinae consists of five tribes, Proterotaphini tr.n., Macrolycinellini tr.n., Dictyopterini, Taphini and Lycoprogentini, and is distributed in the Holarctic, Afrotropical, Oriental, Papuan, Neotropical and Australian regions (Map 10). Interestingly, the continuity of the distribution area in the Palaearctic and Nearctic is due to one widely distributed species — otherwise the Holarctic distribution would be disjunctive.

REMARKS. The genus Macrolycinella Pic, 1922 does not share certain diagnostic characters with the other dictyopterines and is classified in Dictyopterinae in accordance with the cladistic analysis [Kazantsev, 2010] as a new tribe, Macrolycinellini tr.n.

\section{Proterotaphini Kazantsev tr.n.}

Type genus: Proterotaphes Kazantsev, 2006.

DIAGNOSIS. Proterotaphini tr.n. differs from other erotines by a combination of the complete pronotal carinae with rhomboidal pronotal areole, divided labrum (Fig. 10), long spiculum ventrale and long proximal portion of the ultimate tergite (Figs 11-12) and shortened parameres of the aedeagus (Figs 13-14). The divided labrum is not known in other adult Coleoptera [Crowson, 1981]. As studies on lycid prekatatrepsis embryos [Cicero, 1994] indicate that at the embryonic stage lycids have the labrum divided into two separate lobes, this character in Proterotaphes appears to be its plesiomorphy. The shortened parameres of the aedeagus in the new tribe seem to be homoplastic with the shortened parameres in Macrolycinellini tr.n. [Kazantsev, 2004; 2010]

DISTRIBUTION. Proterotaphini tr.n. includes just one genus - Proterotaphes Kazantsev, 2006, known from only one type specimen from New South Wales, Australia (Map 4).

\section{Macrolycinellini Kazantsev tr.n.}

Type genus: Macrolycinella Pic, 1922.

DIAGNOSIS. Macrolycinellini tr.n. differs from other erotines by a combination of the complete longitudinal and transverse pronotal carinae with short posterior areole (Fig. $15)$ and the elongate median piece of aedeagus with shortened parameres (Fig. 16). The shortened parameres of the aedeagus of the new tribe seem to be homoplastic with the shortened parameres in Proterotaphini tr.n. [Kazantsev, 2004; 2010]

DISTRIBUTION. Macrolycinellini tr.n. includes only one genus, Macrolycinella, distributed in Mesoamerica (Mexico) (Map 4).

\section{Dictyopterini Houlbert, 1922}

Type genus: Dictyoptera Latreille, 1829

DIAGNOSIS. Dictyopterini may be distinguished from other tribes of Dictyopterinae by a combination of the more or less regular pronotal areole (Figs 2, 20-23), long narrow spiculum ventrale of ultimate male ventrite and long narrow spiculum gastrale of ultimate female ventrite, as well as long free narrow valvifers of the external female genitalia (Fig. 19).

DISTRIBUTION. Dictyopterini is composed of two subtribes, Dictyopterina and Flagraxina, distributed in the Holarctic, Afrotropical and Oriental regions (Maps 5-6). The continuity of the distribution area in the Palaearctic and Nearctic is due to one widely distributed species - otherwise the Holarctic distribution would be disjunctive.

\section{Dictyopterina Houlbert, 1922}

Type genus: Dictyoptera Latreille, 1829.

DIAGNOSIS. Dictyopterina may be distinguished from Flagraxina by a combination of the conspicuous median pronotal areole with straight or convex posterior carinae, absent wedge cell of the metathoracic wing, unmodified distal margin of penultimate male ventrite [Kazantsev, 2006].

DISTRIBUTION. Dictyopterina is registered in the Holarctic and Oriental regions (Map 5), the continuity of the distribution area in the Palaearctic and Nearctic is due to one widely distributed species, Dictyoptera aurora Herbst, 1784 - without this species the distribution area in the Holarctic would be almost as disjunctive as that of Lopherotini (Fig. 3). The subtribe includes twelve species-poor genera, Dictyoptera Latreille, 1829, Pyropterus Mulsant, 1838, Helcophorus Fairmaire, 1891, Parataphes Kleine, 1925, Benibotarus Kôno, 1932, Propyropterus Nakane, 1968, Kolibaceum Winkler, 1987, Punicealis Kazantsev, 1990, Greenarus Kazantsev, 1995, Taphomimus Kazantsev, 1996, Chinotaphes Bocák \& 
Bocáková, 1999 and Pyrotes Kazantsev, 2004. Two of the genus-group taxa, Helcophorus and Kolibaceum, have extinct members in the Baltic amber.

\section{Taphomimus huaphanensis Kazantsev sp.n.}

Figs 2, 17-19

MATERIAL: Holotype, $\sigma^{7}$, E Laos, Hua Phan prov., Ban Saleui, Phou Pan Mt., $20^{\circ} 122^{\prime} \mathrm{N}, 104^{\circ} 01^{\prime} \mathrm{E}, 1300-1900 \mathrm{~m}, 1-31 . \mathrm{V} .2011$, C. Holzschuh leg. (ICCM); paratypes: 3 우, same label (ICCM).

DESCRIPTION. Male. Black. Head, pronotum and elytra dark red (Fig. 2).
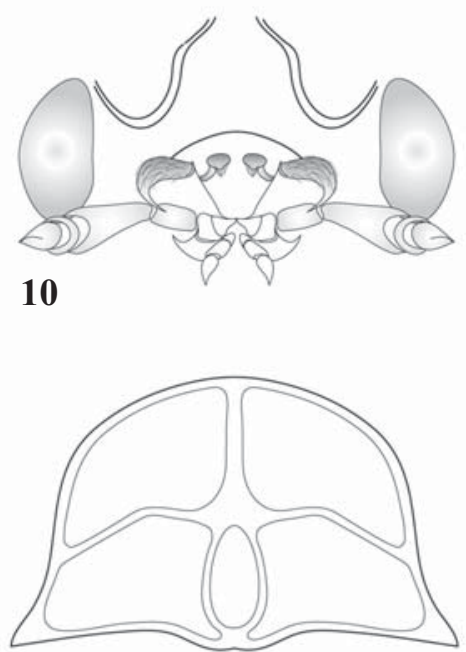

15
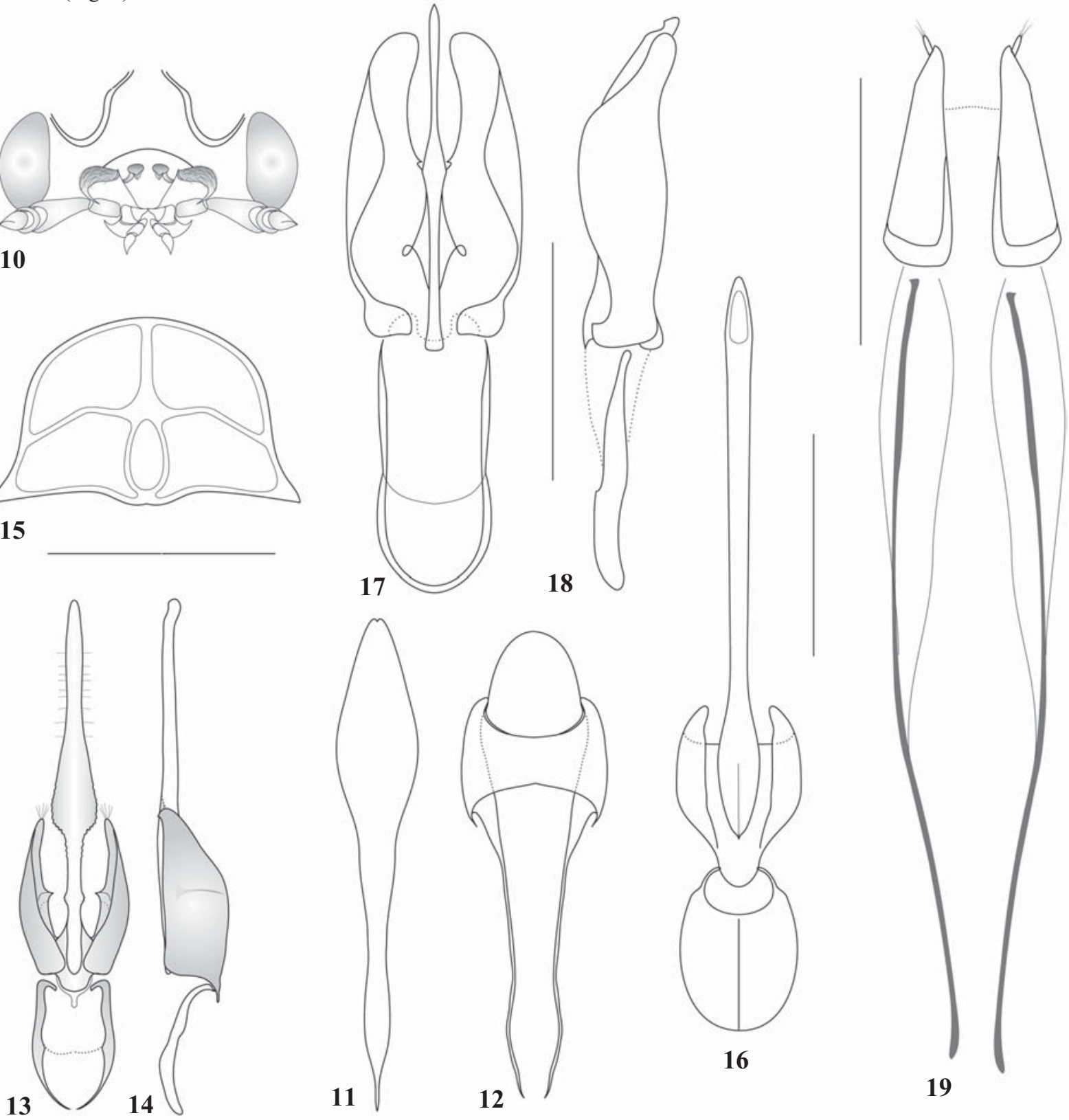

Figs 10-19. Details of Dictyopterinae: 10-14 _ Proterotaphes sempiternus; 15-16 — Macrolycinella bicolor; 17-19 — Taphomimus huaphanensis sp.n.; 10 - head anteriorly; 11-12 - male terminal abdominal segments; 15 - pronotum; 13-14, 16, 17-18 - aedeagus; 19 - external genitalia; 11-13, 15-17, 19 - dorsal view; 14, 18 - lateral view; 7-18 - holotype male; 19 - paratype female; . Scale bar: 5 mm. [Figs 10-14 given after Kazantsev, 2004; Figs 15-16 — after Kazantsev, 2010]

Рис. 10-19. Детали строения Dictyopterinae: 10-14 — Proterotaphes sempiternus; 15-16 — Macrolycinella bicolor; 17-19 — Taphomimus huaphanensis sp.n.; 10 - голова спереди; 11-12 - вершинные сегменты брюшка самца; 15 - переднеспинка; 13-14, 16, 17-18 - эдеагус; 19 - наружные гениталии; 11-13, 15-17, 19 - сверху; 14, 18 - сбоку; 17-18 - голотип, самец; 19 - паратип, самка. Масштабная линейка: 5 мм. [Рис. 7-9 даны по Kazantsev, 2004; Рис. 15-16 - по Kazantsev, 2010] 
Pronotum transverse, 1.4 times wider than long, slightly trapezoidal, with noticeable anterior and small acute posterior angles, anterior margin mildly rounded; anterior sides of median areole slightly concave (Fig. 2). Scutellum subquadrate, almost parallel-sided, conspicuously emarginate at apex.

Elytra long (3.6 times as long as wide humerally), parallel-sided, with all four primary costae equally developed, except slightly weaker costa 1 in distal two thirds, and reaching elytral apices; interstices with one row of regular transverse cells. Short decumbent pubescence distributed along longitudinal (rather dense pubescence) and transverse (separate hairs) costae (Fig. 2).

Ultimate ventrite with long narrow spiculum ventrale; penultimate tergite without median suture. Aedeagus relatively robust, with curved median lobe, slightly widened in the middle, spinose parameres and long and long narrow phallobase, considerably narrower than parameres and only slightly shorter than median lobe (Figs 17-18).

Female. Similar to male, but antennae noticeably shorter. Ultimate ventrite with long narrow spiculum gastrale. External genitalia with relatively robust free coxites, free long narrow valvifers and small elongate styli (Fig. 19).

Length: 6.3-8.2 mm. Width (humerally): $1.6-2.1 \mathrm{~mm}$.

ETYMOLOGY. The new species is named after the province in Laos, where the type series was collected.

DIAGNOSIS. Taphomimus huaphanensis sp.n. seems to be allied to T. diocisus (Bocák \& Bocáková, 1991), distinguishable by the narrower and distinctly widened proximally median lobe of the aedeagus (Figs 17-18).

\section{Dictyoptera quadricostata (Pic, 1927)}

Pyropterus quadricostatus Pic, 1927: 6.

Pyropterus bicoloricornis Pic, 1933: 110, syn.n.

Dictyoptera bicoloricornis (Pic, 1933): Bocák \& Bocáková, 1991: 315

MATERIAL: $2 \bigcirc^{7} \Im^{7}, \mathrm{~N}$ Vietnam, Chapa, Fan-Si-Pan Mt., N Seite, 1600 m, prim. Urwald, 25-30.III.1995, Schintimeister leg.; $15 \sigma^{\top} \sigma^{7}$ and 18 우, E Laos, Hua Phan prov., Ban Saleui, Phou Pan Mt., $20^{\circ} 122^{\prime} \mathrm{N}, 104^{\circ} 01^{\prime} \mathrm{E}, 1300-1900 \mathrm{~m}, 1-31 . \mathrm{V} .2011$, C. Holzschuh leg. (ICCM)

REMARKS. The study of a longer series of Dictyoptera quadricostata, mostly from eastern Laos, has demonstrated that D. quadricostata and D. bicoloricornis represent a single taxon: the reddish ultimate antennomere given by Bocák \& Bocáková [1991] as the differential character, has turned out to fall within range of variation of $D$. quadricostata. Bocák \& Bocáková examined only three syntype specimens of both taxa, the female lectotype and male paralectotype of $D$. quadricostata and the male lectotype of $D$. bicoloricornis. They noted that the paralectotype of $D$. quadricostata (from which the aedeagus of «D. quadricostata» was illustrated) did not quite match the lectotype, differing by the black first antennomere and legs and shape and structure of the pronotum. While the lectotypes of $D$. quadricostata and $D$. bicoloricornis apparently belong to a single taxon, there is actually little doubt that the paralectotype of $D$. quadricostata (from «Ton Hai Katoni») represents a different species, possibly conspecific with D. laosensis (Pic, 1926) (described also from «Ton Hai Katoni»).

\section{Dictyoptera laosensis (Pic, 1926)}

Figs 24-25

Conderis laosensis Pic, 1926: 23: 6

Dictyoptera laosensis (Pic, 1926): Kazantsev, 1993: 61

MATERIAL: Lectotype, + , «Laos, Ton Hai Katoni, 6.IV.1918, R. Vitalis de Salvaza», «type», «Conderis laosensis n. sp.» (Pic's manuscript label), «Lectotype, S. Kazantsev des. 1993» (MNHN);
フ , Vietnam, Gialai Kontum prov., Buon Loi, 18.I.1990, O. Gorbunov leg.; + , Vietnam, Gia Lai Kon Tum prov., Son Lang, Buon Loi, Kontjarang, 7.I.1988, Y. Zaitsev leg. (ICCM).

\section{Dictyoptera phoupanensis Kazantsev sp.n.}

Figs 20, 26-27

MATERIAL: Holotype, $\bigcirc^{7}$, E Laos, Hua Phan prov., Ban Saleui, Phou Pan Mt., $\sim 20^{\circ} 122^{\prime} \mathrm{N}, 104^{\circ} 01^{\prime} \mathrm{E}, 1300-1900 \mathrm{~m}, 1-31 . V .2011$, C. Holzschuh leg. (ICCM); paratypes: $6 \sigma^{\top} \sigma^{7}, 1$, same label (ICCM).

DESCRIPTION. Male. Black. Pronotum, except bottom of median areole, and elytra dark red.

Head dorsally very finely and densely punctured, with triangular transverse impression behind antennal prominence and longitudinal median impression between antennal tubercles; antennal prominence inconspicuous, antennal sockets separated by noticeable lamina. Eyes small (separated medially above by about 3 times their radius). Ultimate maxillary palpomere elongate, conspicuously widened and flattened distally. Antennae long, extending to elytral five sixths, filiform; antennomeres 4-9 slightly widened distally; antennomere 3 transverse, subequal in length to antennomere 2; antennomeres 4-11 with short dense erect pubescence (Fig. 22).

Pronotum transverse, 1.25 times wider than long, trapezoidal, with blunt anterior and acute posterior angles, produced into long narrow processes; anterior margin mildly rounded; median areole short, not reaching posterior margin; anterior sides of median areole slightly concave (Fig. 22). Scutellum elongate, parallel-sided, slightly emarginate at apex.

Elytra long (ca. 3 times as long as wide humerally), slightly widened distally, with all four primary costae equally developed and reaching elytral apices; interstices with two rows of subquadrate cells. Short decumbent pubescence distributed along longitudinal (rather dense pubescence) and transverse (separate hairs) costae (Fig. 22).

Penultimate ventrite deeply incised.

Aedeagus with narrow, provided with three spines near apex median lobe and shortened and spinose parameres; phallobase with inconspicuous median suture (Figs 24-25).

Female. Similar to male, but antennae somewhat shorter.

Length: 9.0-10.0 mm. Width (humerally): 2.6-2.9 mm.

ETYMOLOGY. The new species is named after the mountain, where the type series was collected.

DIAGNOSIS. Dictyoptera phoupanensis sp.n. differs from somewhat similar $D$. laosensis by the long narrow processes of hind angles and shorter, not reaching posterior margin median areole of the pronotum, mostly black scutellum, narrow, provided with three spines near apex median lobe, and shortened and spinose parameres of the aedeagus (Figs 24-25).

\section{Dictyoptera panicola Kazantsev sp.n.} Figs 21, 28-29

MATERIAL: Holotype, $\sigma^{7}$, E Laos, Hua Phan prov., Ban Saleui, Phou Pan Mt., $\sim 20^{\circ} 12^{\prime} \mathrm{N}, 104^{\circ} 01^{\prime} \mathrm{E}, 1300-1900 \mathrm{~m}, 1-31 . \mathrm{V} .2011$, C. Holzschuh leg. (ICCM); paratypes: $5 \sigma^{\top} \sigma^{7}, 4$ 우, same label (ICCM).

DESCRIPTION. Male. Black. Head, pronotum, scutellum and elytra bright red.

Head dorsally very finely punctured, with feeble transverse impression behind antennal prominence; antennal prominence inconspicuous, antennal sockets separated by noticeable lamina. Eyes small (separated medially above by ca. 3.6 times their radius). Ultimate maxillary palpomere elongate, oblique and flattened at apex, widened in the middle. Antennae long, extending to elytral three fourths, filiform; antennomere 3 

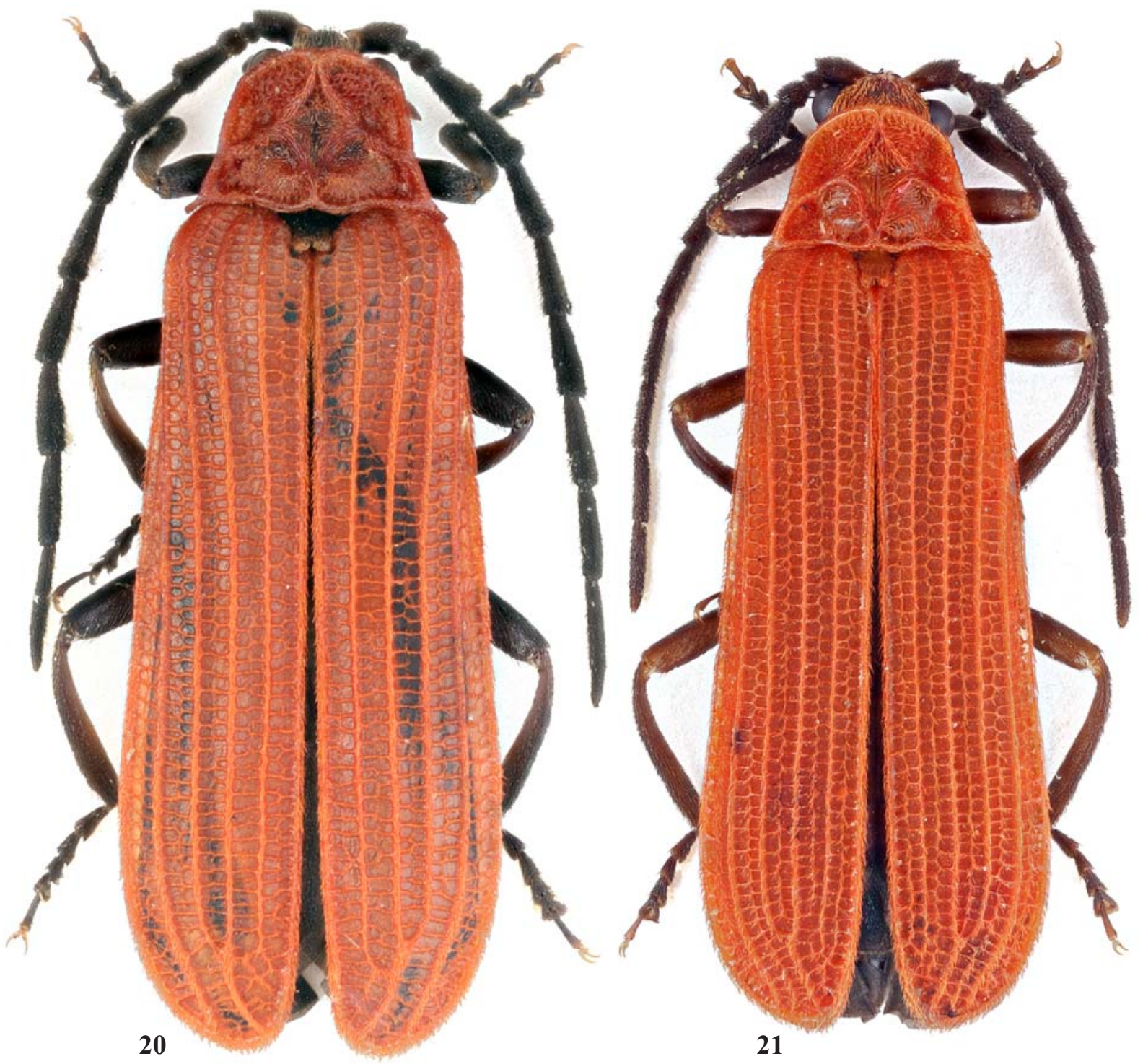

Figs 20-21. General view of Dictyoptera spp.: $20-$ D. phoupanensis sp.n.; $21-$ D. panicola sp.n.; 20-21 - holotype males. Рис. 20-21. Общий вид Dictyoptera spp.: $20-D$. phoupanensis sp.n.; $21-D$. panicola sp.n.; 20-21 - голотипы, самцы.

subquadrate, ca. 1.6 times longer than antennomere 2; antennomeres 4-11 with short dense erect pubescence (Fig. 21).

Pronotum transverse, 1.2 times wider than long, trapezoidal, with noticeable anterior and prominent acute posterior angles; anterior margin rounded; median areole reaching posterior margin; anterior sides of median areole straight, posterior sides concave (Fig. 21). Scutellum elongate, almost parallel-sided, slightly emarginate at apex.

Elytra long (ca. 3 times as long as wide humerally), slightly widened distally, with all four primary costae equally developed and reaching elytral apices; interstices with two rows of subquadrate cells. Short decumbent pubescence distributed along longitudinal and transverse (as separate hairs) costae (Fig. 21).

Penultimate ventrite with almost straight and medially lifted distal margin.

Aedeagus with conspicuously dilated in the middle median lobe, protruding outside parameral tube and straight, relatively robust parameres with inner teeth located close to apex (Figs 28-29).
Female. Similar to male, but slightly more robust, penultimate ventrite not lifted and antennae somewhat shorter.

Length: 8.8-9.7 mm. Width (humerally): $2.3-2.7 \mathrm{~mm}$.

ETYMOLOGY. The new species is named after the mountain, where the type series was collected.

DIAGNOSIS. Dictyoptera panicola sp.n. seems to be related to $D$. quadricostata, having the same structure of terminal ventrites, differing by the uniformly black antennae and legs, less lifted penultimate ventrite, conspicuously widened in the middle and protruding outside the parameral tube median lobe of the aedeagus (Figs 28-29).

\section{Dictyoptera laomontana Kazantsev sp.n.}

Figs 30-32

MATERIAL: Holotype, $\sigma^{\top}$, E Laos, Hua Phan prov., Ban Saleui, Phou Pan Mt., $20^{\circ} 12^{\prime} \mathrm{N}, 104^{\circ} 01^{\prime} \mathrm{E}, 1300-1900 \mathrm{~m}, 1-31 . \mathrm{V} .2011$, C. Holzschuh leg. (ICCM); paratypes: 10 우, same label (ICCM).

DESCRIPTION. Male. Black. Pronotum, except bottom of median and postero-lateral areoles, and elytra dark red.

Head dorsally very finely and densely punctured, with 


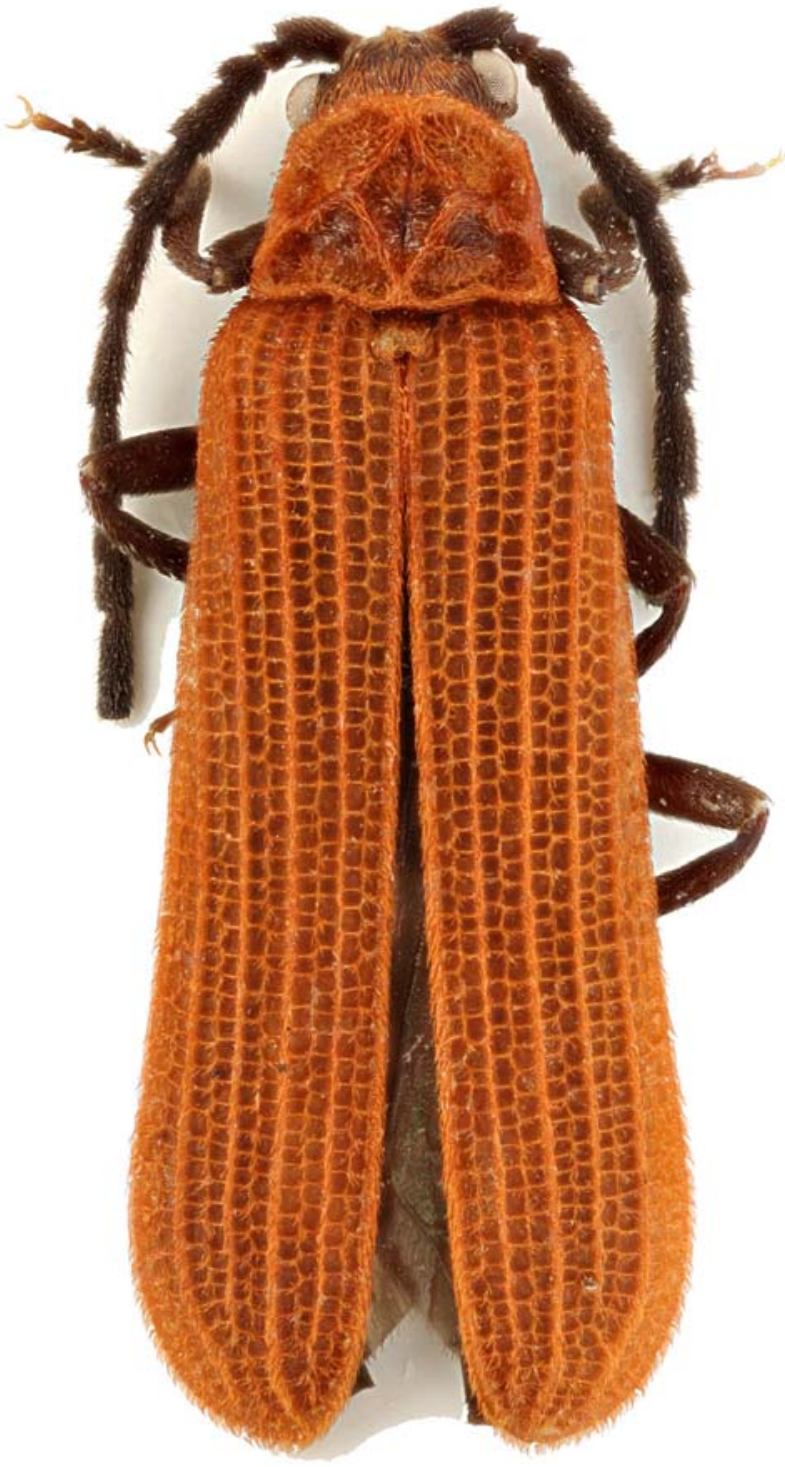

22

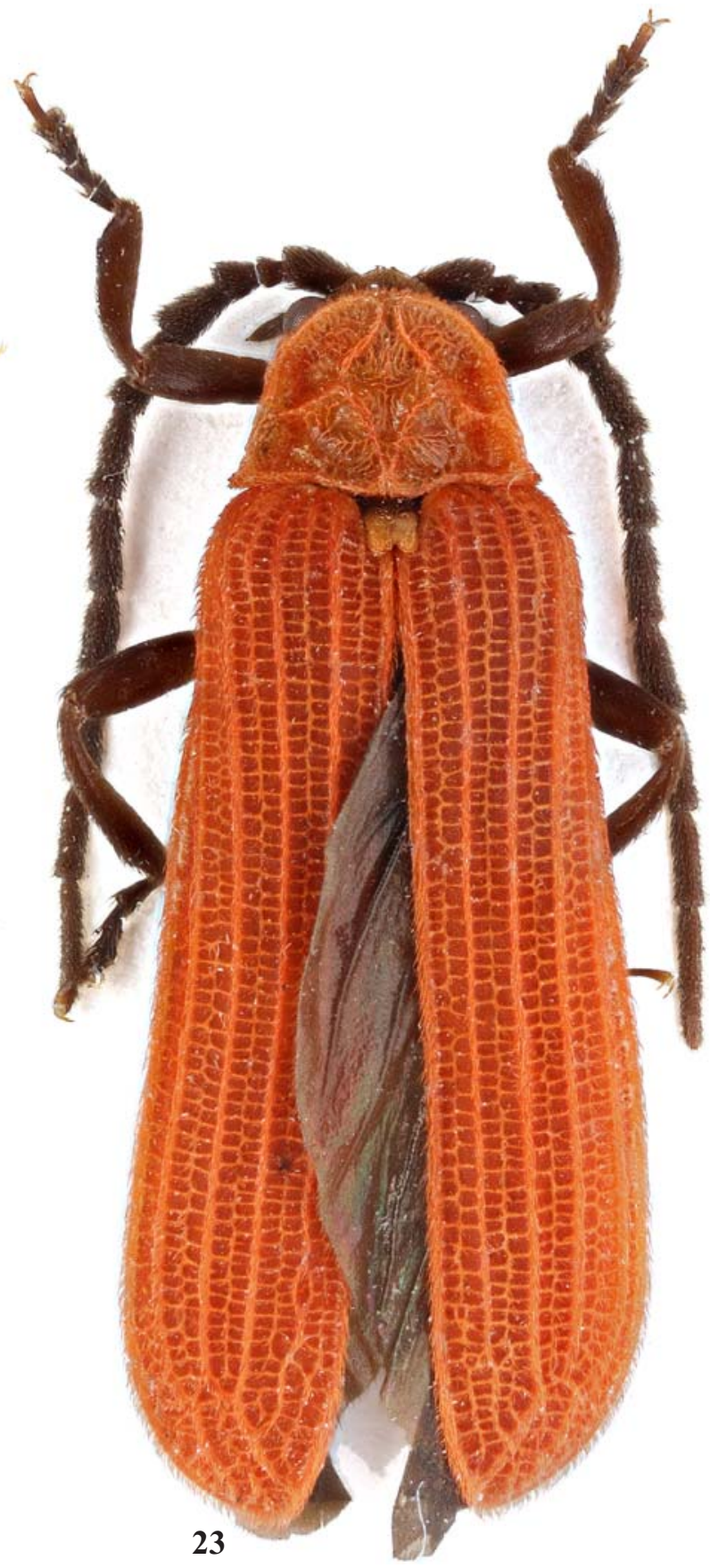

Figs 22-23. General view of Dictyoptera spp.: $22-$ D. recticarinata sp.n.; $23-$ D. triachroma sp.n.; $22-23$ - holotype males. Рис. 22-23. Общий вид Dictyoptera spp.: 22 - D. recticarinata sp.n.; 23 - D. triachroma sp.n.; 22-23 — голотипы, самцы.

triangular impression behind antennal prominence and longitudinal median impression between antennal tubercles; antennal prominence inconspicuous, antennal sockets separated by noticeable lamina. Eyes small (separated medially above by about 3.2 times their radius). Ultimate maxillary palpomere subquadrate, conspicuously widened and flattened distally. Antennae moderately long, extending to elytral two thirds, filiform; antennomeres 4-9 slightly widened distally; antennomere 3 transverse, subequal in length to antennomere 2; antennomeres 4-11 with short dense erect pubescence.
Pronotum transverse, 1.4 times wider than long, with almost parallel sides, bulging anterior and prominent acute posterior angles; anterior margin rounded; median areole short, not quite reaching anterior and posterior margins; anterior sides of median areole almost straight, posterior slightly concave. Scutellum elongate, parallel-sided, slightly emarginate at apex.

Elytra long (ca. 3 times as long as wide humerally), slightly widened distally, with all four primary costae equally developed and reaching elytral apices, except costa 1, apparently weaker in distal two third and not reaching apex; 
interstices with two rows of subquadrate or elongate cells. Short decumbent pubescence distributed along longitudinal and transverse (as separate hairs) costae.

Penultimate ventrite deeply incised. Metatrochanters with acute posterior angles.

Aedeagus with slightly dilated median lobe, provided with three processes at apex, relatively robust, constricted distally parameres and long, almost as long as parameres, and medially weakly sclerotized phallobase, provided with median tooth at trough of incision (Figs 28-29).
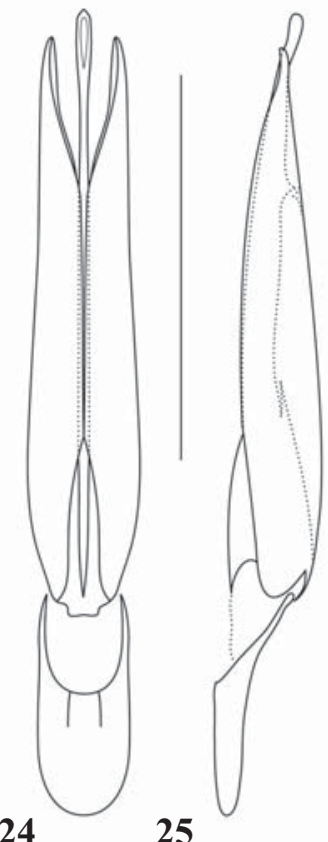

25

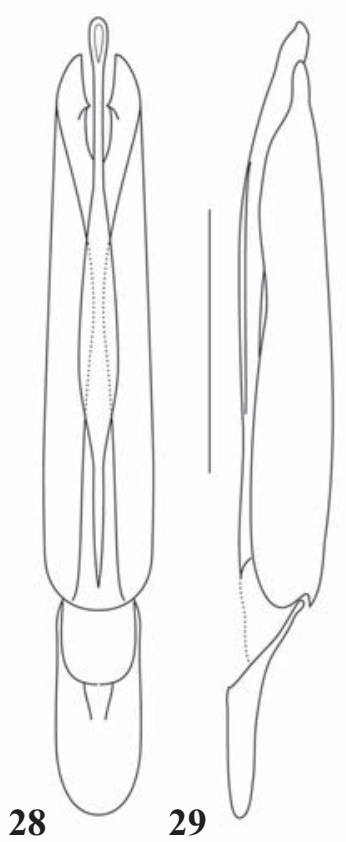

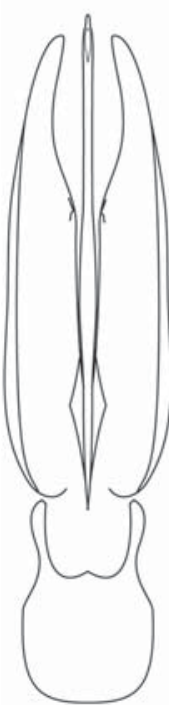

33

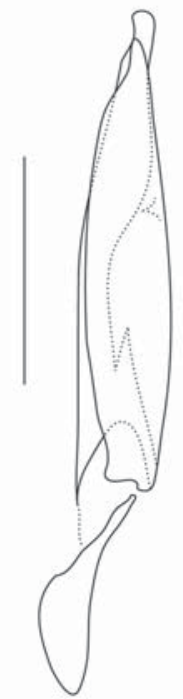

34

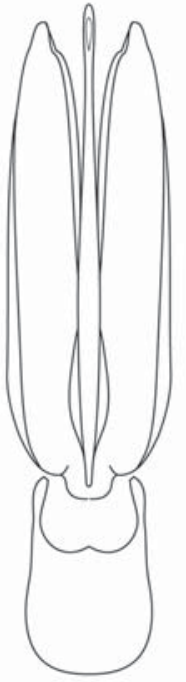

35

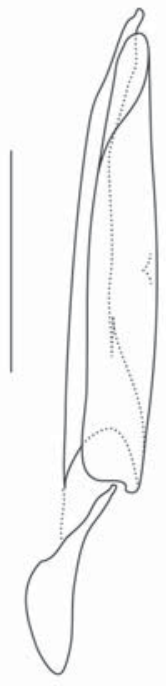

36
Female. Similar to male, but antennae somewhat shorter. External genitalia with long free narrow straight valvifers (Fig. 30).

Length: $8.0-10.8 \mathrm{~mm}$. Width (humerally): $2.0-3.0 \mathrm{~mm}$.

ETYMOLOGY. The name of the new species is derived from «Laos», the name of the country where it was collected, and «montanus», the Latin for «montane», alluding to the altitude where it occurs.

DIAGNOSIS. Dictyoptera laomontana sp.n. is fairly similar to D. gansuensis Kazantsev, 2004 from Central Chi-

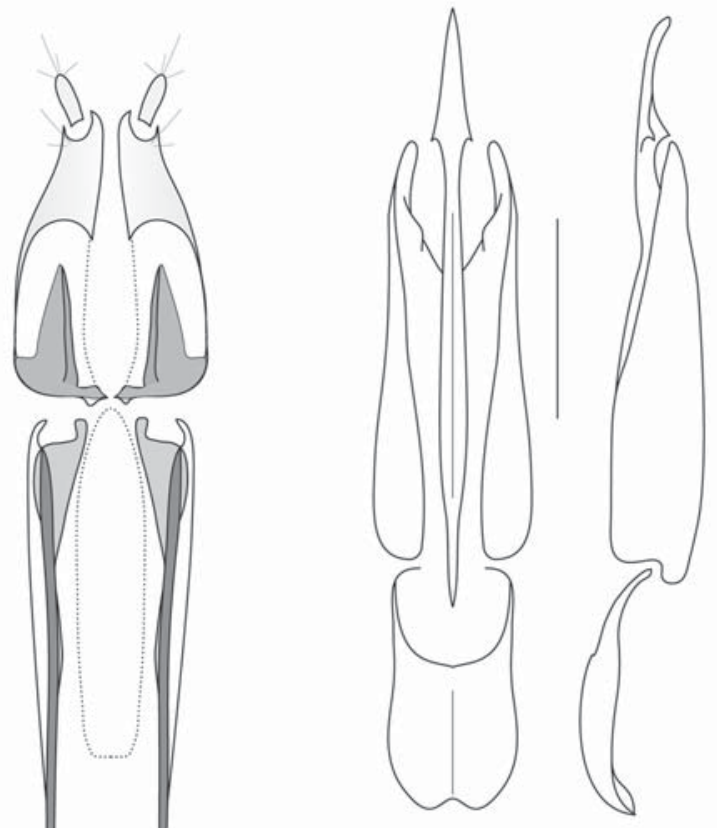

26

27

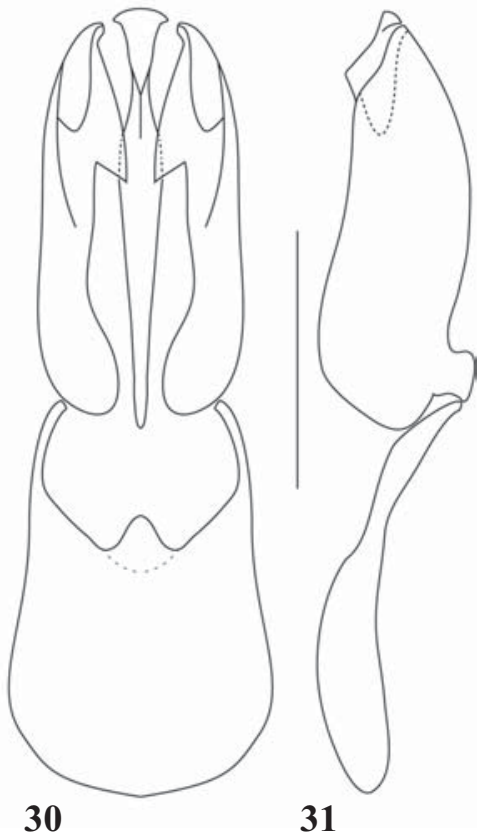

Figs 24-36. Details of Dictyoptera spp.: 24-25 - D. laosensis; 26-27 - D. phoupanensis sp.n.; 28-29 - D. panicola sp.n.; 30-32D. laomontana sp.n.; 33-34 - D. recticarinata sp.n.; 35-36 - D. triachroma sp.n.; 24-31, 33-36 - aedeagus; 32 - external genitalia; 24, 26, 28, 30, 32-33, 35 - dorsal view; 25, 27, 29, 31,34,36 - lateral view; 26-31, 33-36 - holotype males; 32 - paratype female. Scale bar: $5 \mathrm{~mm}$.

Рис. 24-36. Детали строения Dictyoptera spp.: 24-25 - D. laosensis; 26-27 - D. phoupanensis sp.n.; 28-29 - D. panicola sp.n.; 30-32 - D. laomontana sp.n.; 33-34 - D. recticarinata sp.n.; 35-36 - D. triachroma sp.n.; 24, 26, 28, 30, 32-33, 35 - cверху; 25, 27, 29,31, 34, 36 - сбоку; 24-31, 33-36 - эдеагус; 32 - наружные гениталии; 26-31, 33-36 - голотипы, самцы; 32 - паратип, самка. Масштабная линейка: 5 мм. 
na, distinguishable by the less dilated median lobe and somewhat narrower parameres of the aedeagus (Figs 28-29).

REMARKS. Dictyoptera laomontana sp.n. share with $D$. gansuensis the long and medially weakly sclerotized phallobase, almost reaching parameres in length (Figs 2829) - this seems to be a symplesiomorphy with the tribe Taphini.

\section{Dictyoptera recticarinata Kazantsev sp.n.} Figs 22, 33-34

MATERIAL: Holotype, $0^{7}$, N Laos, $15 \mathrm{~km}$ NW Louang Namtha, $21^{\circ} 07.52^{\prime} \mathrm{N}, 104^{\circ} 21.0^{\prime} \mathrm{E}, 750 \mathrm{~m}, 13-24$.V.1997, Strba \& Hergovits leg. (ICCM).

DESCRIPTION. Male. Black. Pronotum, except fuscous bottom of areoles in posterior half, scutellum and elytra bright red; head and antennomeres 1-2 with reddish pubescence.

Head dorsally finely and rather scarcely punctured, with feeble triangular impression behind antennal prominence and median groove on vertex; antennal prominence inconspicuous, antennal sockets separated by noticeable lamina. Eyes small (separated medially above by ca. 3.2 times their radius). Ultimate maxillary palpomere elongate, conspicuously widened and flattened distally. Antennae moderately long, extending to elytral two thirds, filiform; antennomeres 4-9 slightly widened distally; antennomere 3 subquadrate, ca. 1.3 times longer than antennomere 2; antennomeres 4-11 with short dense erect pubescence (Fig. 31).

Pronotum transverse, 1.4 times wider than long, trapezoidal, with blunt anterior and acute posterior angles; anterior margin rounded; median areole reaching anterior and posterior margins; anterior sides of median areole concave, posterior sides straight (Fig. 31). Scutellum elongate, almost parallel-sided, slightly emarginate at apex.

Elytra long (ca. 2.9 times as long as wide humerally), slightly widened distally, with all four primary costae equally developed and reaching elytral apices; interstices with two rows of subquadrate or elongate cells. Short decumbent pubescence distributed along longitudinal and transverse (as separate hairs) costae (Fig. 31).

Penultimate ventrite deeply incised.

Aedeagus with narrow and curved, in lateral view, median lobe, noticeably constricted before apex; inner teeth of parameres at distal two thirds of tube (Figs 33-34).

Female. Unknown.

Length: $7.8 \mathrm{~mm}$. Width (humerally): $2.2 \mathrm{~mm}$.

ETYMOLOGY. The name of the new species is derived from the Latin for «with straight rib», alluding to the straight posterior carinae of its pronotal median areole.

DIAGNOSIS. Dictyoptera recticarinata sp.n. externally resembles $D$. laosensis, differing by the straight posterior sides of its median pronotal areole (Fig. 31), as well as by the narrow and curved median lobe of the aedeagus (Figs 33-34).

\section{Dictyoptera triachroma Kazantsev sp.n.} Figs 23, 35-36

MATERIAL: Holotype, ơ, N Vietnam, Lao Cai, $28 \mathrm{~km} \mathrm{~W}$ Sapa, 22²1'08"N, 10345'64"E, 1940 m, 2.VII.1997, C.-F. Lee leg. (ICCM).

DESCRIPTION. Male. Black. Pronotum and distal half of scutellum orange red; elytra bright red.

Head dorsally finely and scarcely punctured, with feeble semicircular impression behind antennal prominence; antennal prominence inconspicuous, antennal sockets separated by moderately broad lamina. Eyes small (separated medially above by ca. 3.5 times their radius). Ultimate maxillary palpomere elongate, oblique and flattened at apex, widest at proximal fourth. Antennae long, extending to elytral three fourths, filiform; antennomere 3 elongate, ca. 1.8 times longer than antennomere 2; antennomeres 4-11 with short dense erect pubescence (Fig. 23)

Pronotum transverse, 1.4 times wider than long, trapezoidal, with somewhat rounded anterior and prominent acute posterior angles, prolonged in short horizontal processes; anterior margin rounded; median areole reaching posterior margin and somewhat open anteriorly; anterior sides of median areole first convex, then concave, posterior sides slightly concave (Fig. 23). Scutellum elongate, almost parallel-sided, slightly emarginate at apex.

Elytra long (ca. 3 times as long as wide humerally), slightly widened distally, with all four primary costae equally developed and reaching elytral apices; interstices with two rows of regular transverse cells. Short decumbent pubescence distributed along longitudinal and transverse (as separate hairs) costae (Fig. 23).

Penultimate ventrite deeply incised

Aedeagus with narrow and more or less straight median lobe, noticeably incised near apex (as seen in lateral view); inner teeth of parameres at the middle of tube (Figs 35-36).

Female. Unknown

Length: $9.0 \mathrm{~mm}$. Width (humerally): $2.5 \mathrm{~mm}$.

ETYMOLOGY. The name of the new species is derived from the Greek for «three» and «colours», alluding to the coloration of the new species.

DIAGNOSIS. Dictyoptera triachroma sp.n. resembles D. laosensis, D. quadricostata and D. recticarinata sp.n. at the same time, differing by the coloration, with black head, antennae and legs, orange red pronotum and distal half of scutellum and bright red elytra, and by the aedeagus, with narrow and relatively straight median lobe, slightly incised near apex (when observed in lateral view), and inner teeth of parameres at the middle of the tube (Figs 35-36).

\section{Flagraxina Kazantsev, 2004}

Type genus: Flagrax Kazantsev, 1992.

DIAGNOSIS. Flagraxina may be separated from Dictyopterina by a combination of the conspicuous median pronotal areole with convex posterior carinae, developed wedge cell of the metathoracic wing and modified distal margin of penultimate male ventrite. The Flagraxina taxa also have preserved complete discrimen, which seems to be a plesiomorphy of the lineage [Kazantsev, 2006].

DISTRIBUTION. Flagraxina, which consists of three genera, Flagrax Kazantsev, 1992, Phaneros Kazantsev, 1992 and Staepteron Kazantsev, 1992, is confined to Africa, its populations distributed in four isolated pockets (Map 6).

Taphini Bocák \& Bocáková, 1990

Type genus: Taphes Waterhouse, 1878.

DIAGNOSIS. Taphini differs from other dictyopterines by a combination of the modified median pronotal areole, relatively short and convex laterally parameres of the aedeagus with ventral processes, absent or very short spiculum gastrale, and developed proctiger making integral part of the external female genitalia.

DISTRIBUTION. Taphini includes two genera, Taphes Waterhouse, 1878 and Coloberos Bourgeois, 1885, and is confined to the Oriental and Papuan regions (Map 7).

REMARKS. The analysis of distribution of the Dictyopterina taxa leads to a conclusion that Pyropterus incisus Pic, 1925, P. pahanganus Kleine, 1939, P. malaccanus Pic, 1922 and $P$. klossi Blaire, 1928, registered in the Sunda Archipelago and Malaysia, should be attributed not to Pyropterus, but 
to other genera, as all "Pyropterus" species described from this area turned out to belong to other taxa [e.g., Kazantsev, 1996a, 2004]. Therefore, the afore-mentioned species are transferred from Pyropterus to Coloberos Bourgeois, 1885 as $C$. incisus (Pic, 1925), comb.n., C. pahanganus (Kleine, 1939), comb.n., C. malaccanus (Pic, 1922), comb.n. and C. klossi (Blaire, 1928), comb.n.

Lycoprogentini Bocák \& Bocáková, 2008

Type genus: Lycoprogentes Pic, 1915.

DIAGNOSIS. Lycoprogentini may be distinguished by a combination of the broadly attached to the posterior pronotal margin and widest at pronotal anterior third median areola, long phallobase and short rounded parameres of the aedeagus, as well as the wide ovipositor with complex paraprocts and short free valvifers of the female external genitalia [Bocák \& Bocáková, 2008].

DISTRIBUTION. Lycoprogentini includes just one genus, Lycoprogentes Pic, 1915, confined to the Oriental region and south-eastern periphery of the Palaearctic (Map 8).

REMARKS. Lycoprogentes Pic, 1915 and, hence, Lycoprogentini, has been repeatedly misspelt by Bocák \& Bocáková [Bocák \& Bocáková, 1990, 2008; Bocáková \& Bocák, 2007] as Lycoprogenthes.

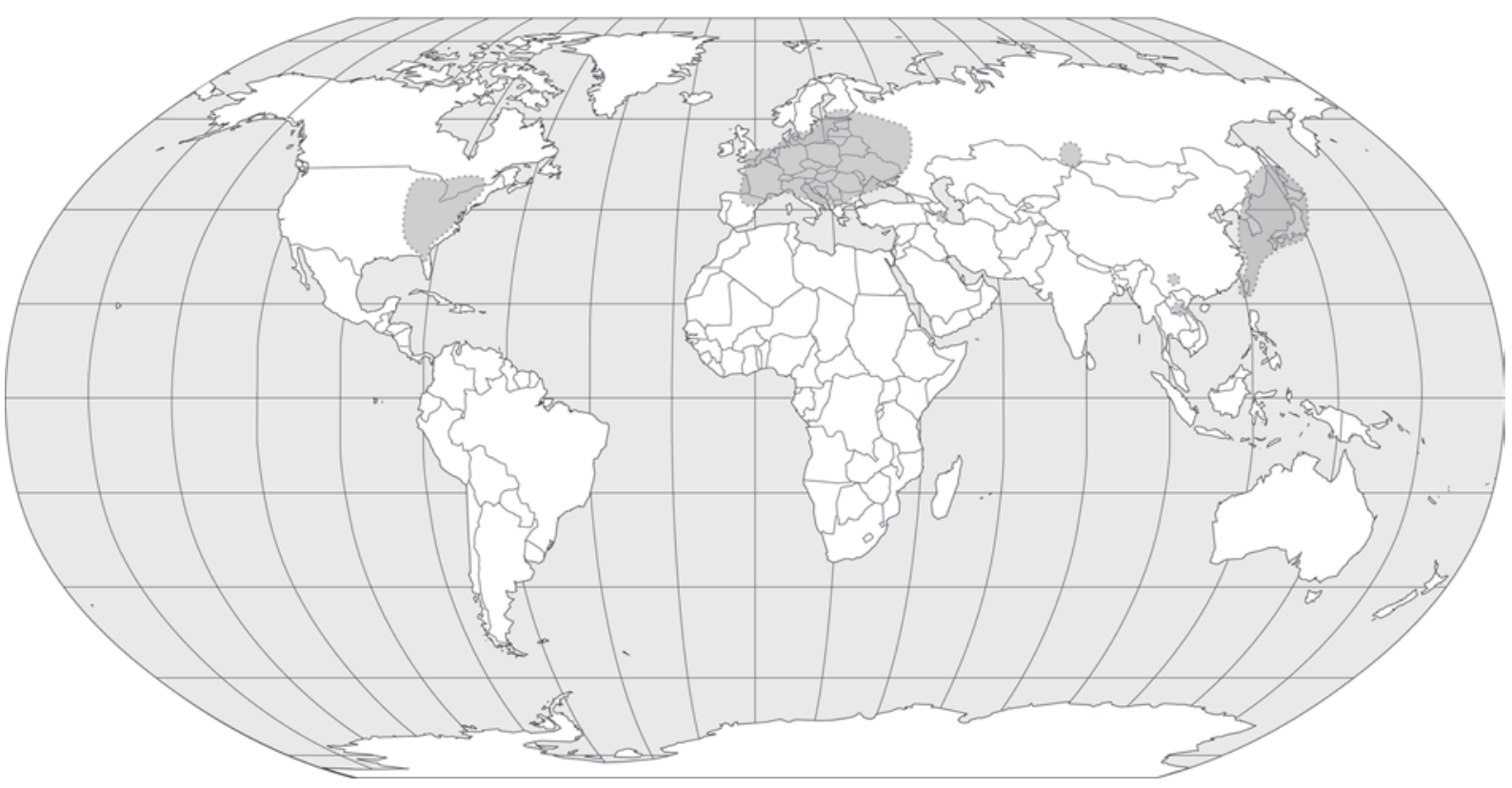

Map 1. Distribution of the subtribe Erotina.

Карта 1. Ареал подтрибы Erotina.

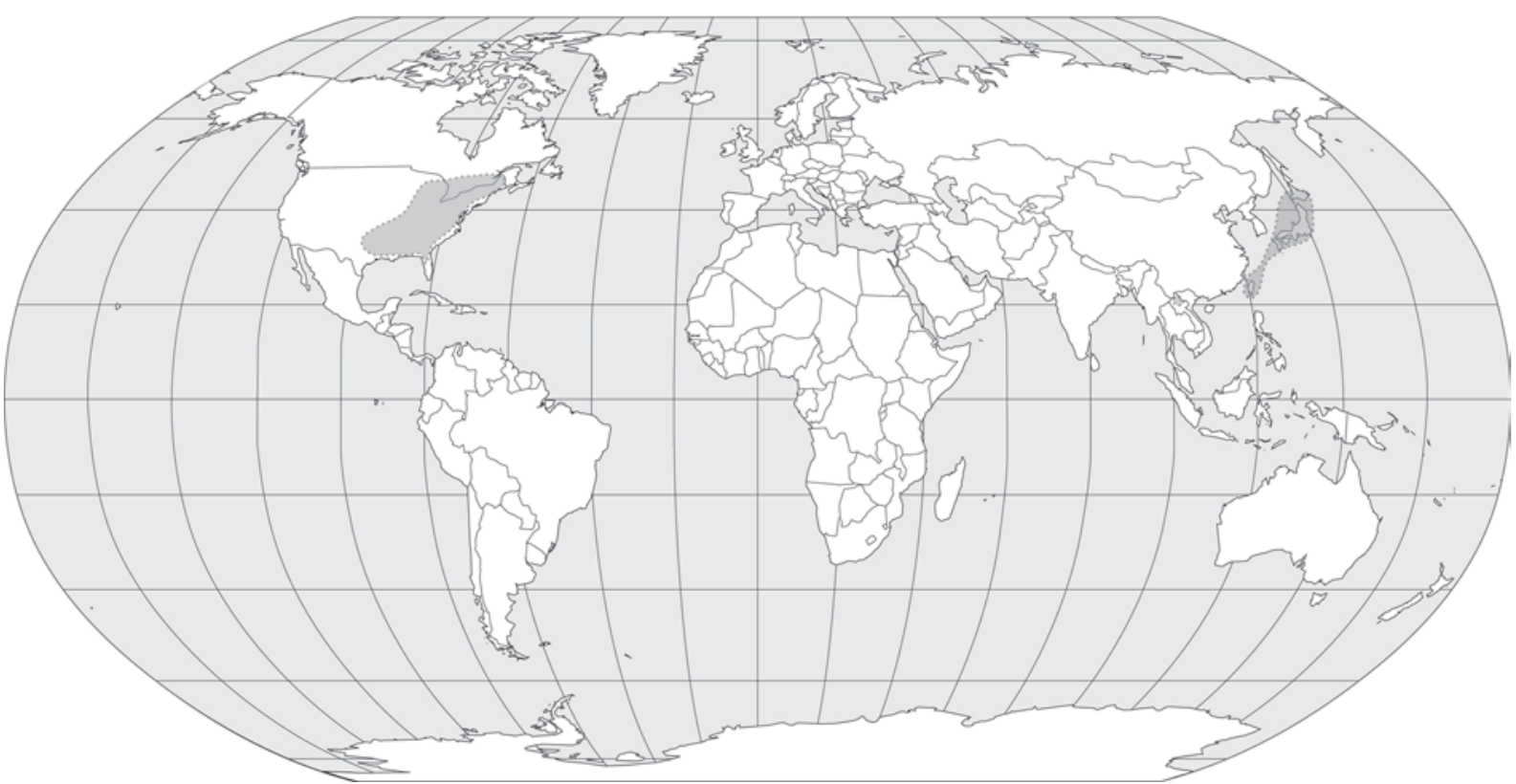

Map 2. Distribution of the subtribe Pseudaplatopterina subtr.n.

Карта 2. Ареал подтрибы Pseudaplatopterina subtr.n. 


\section{Biogeography}

The subfamily Erotinae is unique among the netwinged beetles in being confined to the Holarctic, where its distribution area is represented mostly by isolated patches in commonly acknowledged refuges of both Nearctic and Palaearctic parts, and absent in all regions of Notogaea, Neogaea and Palaeotropics (Map 9). Although the subfamily technically somewhat expands beyond the limits of the Holarctic in northern Laos and
Eastern Himalayas - where a representative of each of Lopheros, Platycides gen.n. and Pseudaplatopterus has been registered - it is conspicuously absent in the Oriental region proper. Distribution of Erotinae species, whose number does not exceed forty altogether, seldom overlap in each genus and often is separated by considerable distances, as distribution of the genera mostly coincides with that of the subfamily [Kazantsev, 2004]. Two genera of Erotinae, Pseudaplatopterus and Protolopheros, are known from the Baltic amber.

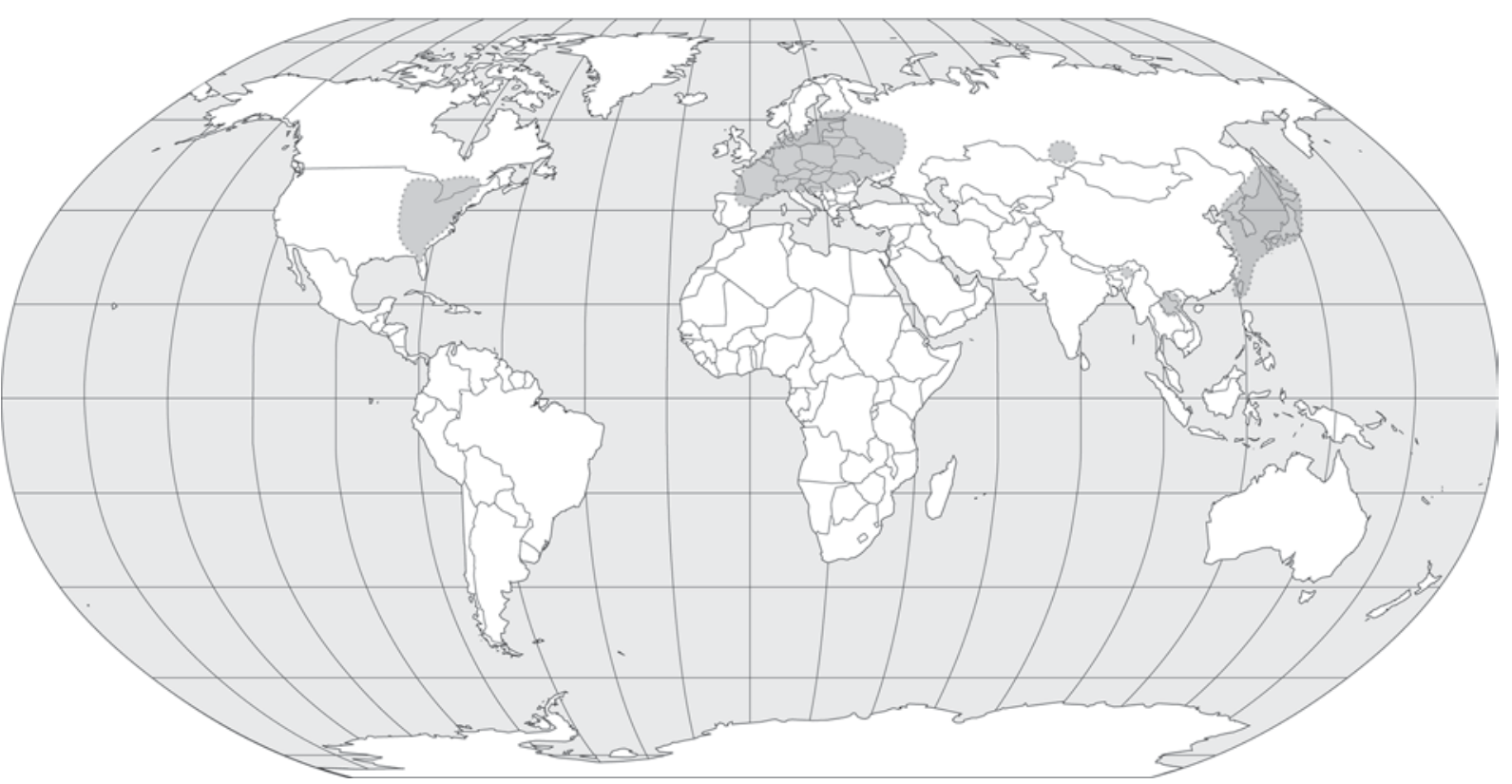

Map 3. Distribution of the tribe Lopherotini tr.n.

Карта 3. Ареал трибы Lopherotini tr.n.

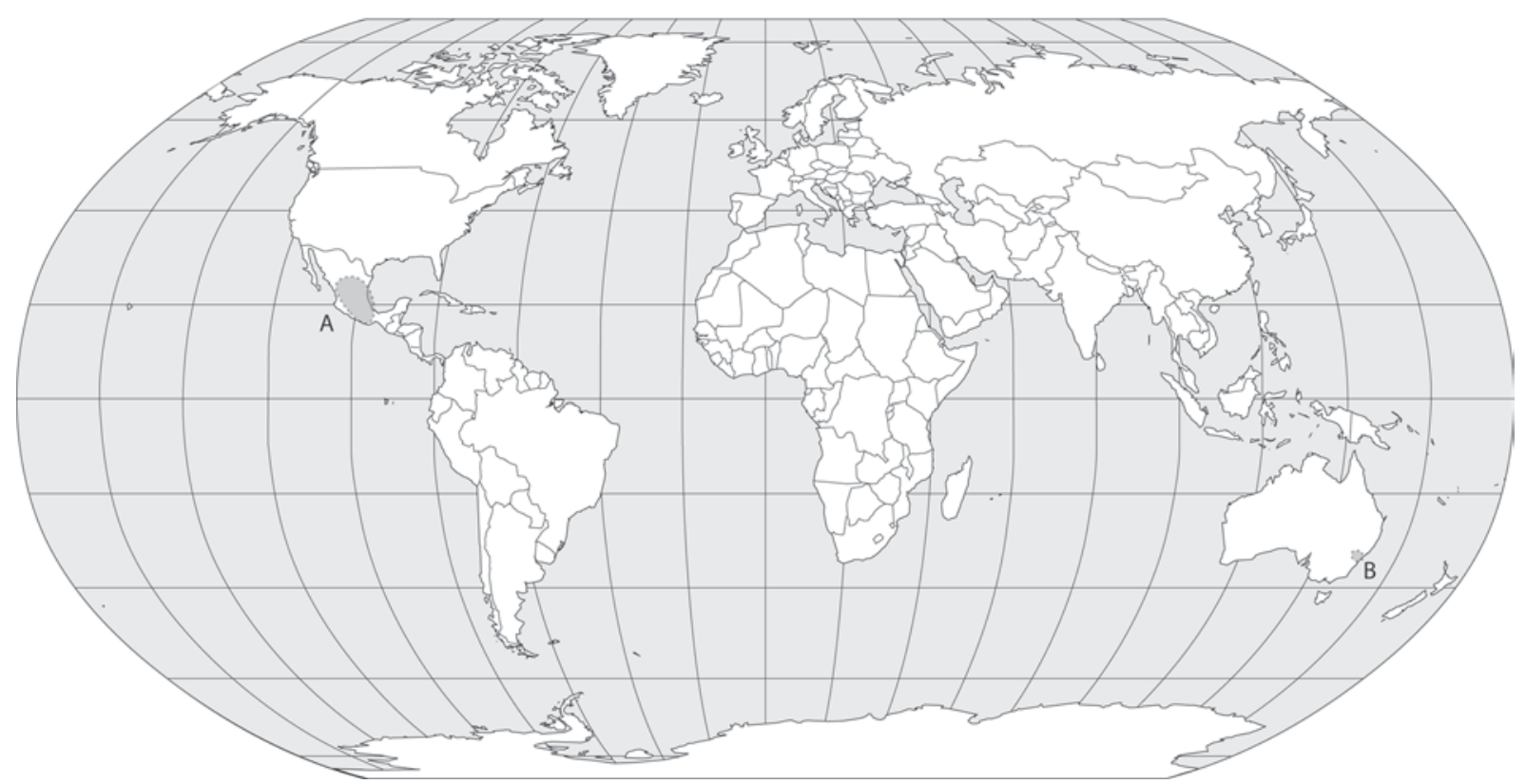

Map 4. Distribution of the tribes Proterotaphini tr.n. (B) and Macrolycinellini tr.n. (A).

Карта 4. Ареал триб Proterotaphini tr.n. (В) и Macrolycinellini tr.n. (А). 
The subfamily Dictyopterinae is unique in a different way, being widely distributed in the Holarctic (in both Nearctic and Palaearctic regions) and Palaeotropics (Afrotropical, Oriental and Papuan regions), also registered in the Australian region of Notogaea, but absent in the Neotropics, Madagascar and New Zealand (Map 10). In Australia it has been reported only from one locality in New South Wales, while in Africa it is known from four isolated pockets. It is noteworthy that the continuity of the distribution area in the Palaearctic and Nearctic is also due to just one widely distributed species, Dictyoptera aurora, - otherwise its populations in the Holarctic would be almost as disjunctive as those of Erotinae (Fig. 9). Two genera of Dictyopterinae, Helcophorus and Kolibaceum, are known from the Baltic amber, the Dictyopterinae and Erotinae so far being the only subfamilies of net-winged beetles found in european ambers [Kazantsev, 2012b].

Taking into account the very low probability of across-the-water dispersal of net-winged beetles in gen-

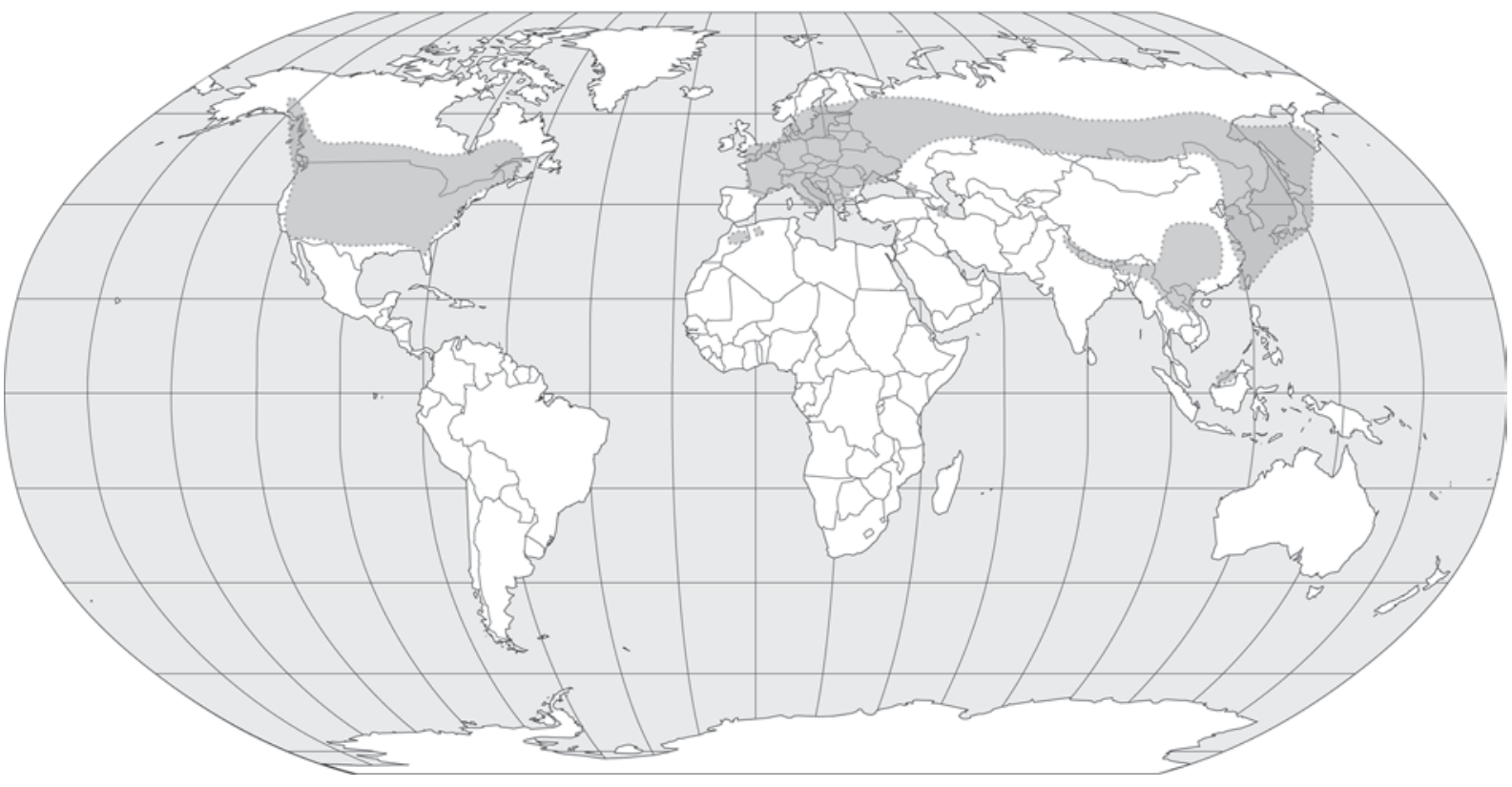

Map 5. Distribution of the subtribe Dictyopterina.

Карта 5. Ареал подтрибы Dictyopterina.

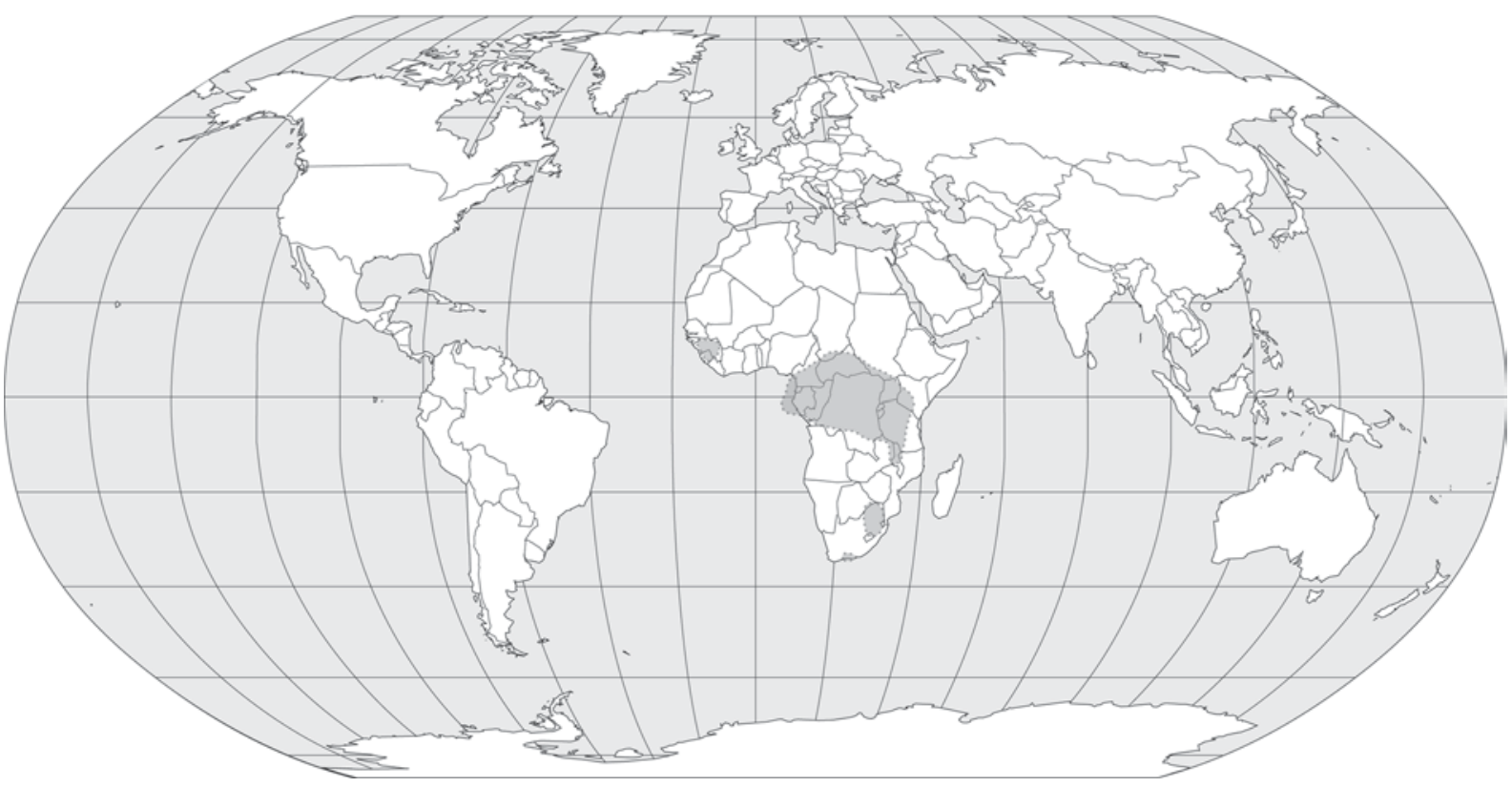

Map 6. Distribution of the subtribe Flagraxina.

Карта 6. Ареал подтрибы Flagraxina. 
eral and of the regarded lineages in particular [e.g., Kazantsev, 2005], and given the continent drift theory is true, the emergence of Dictyopterinae should have predated the Pangaea split, as members of the group are widely distributed in fragments of both former Lavrasia and Gondwana. On the contrary, the emergence of Erotinae should have taken place after the Pangaea split, as its taxa are not registered in fragments of former Gondwanaland, but prior to the supercontinent Lavrasia break-up, i.e. before Laurentia broke free from Eurasia, as erotines occur on all blocs that emerged after the Lavrasia split. In other words, Dictyopterinae appears to be at least 175 million years old, and Erotinae — at least 60 million.

While the absence of the Dictyopterinae in New Zealand and Oceanic archipelagos appears to be due to the repeated submergence of the islands that obliterated their archaic faunas, the fact that they are absent on Madagascar (where only one lycid tribe, Metriorrhynchini, occurs), being well represented in the Afrotropi-

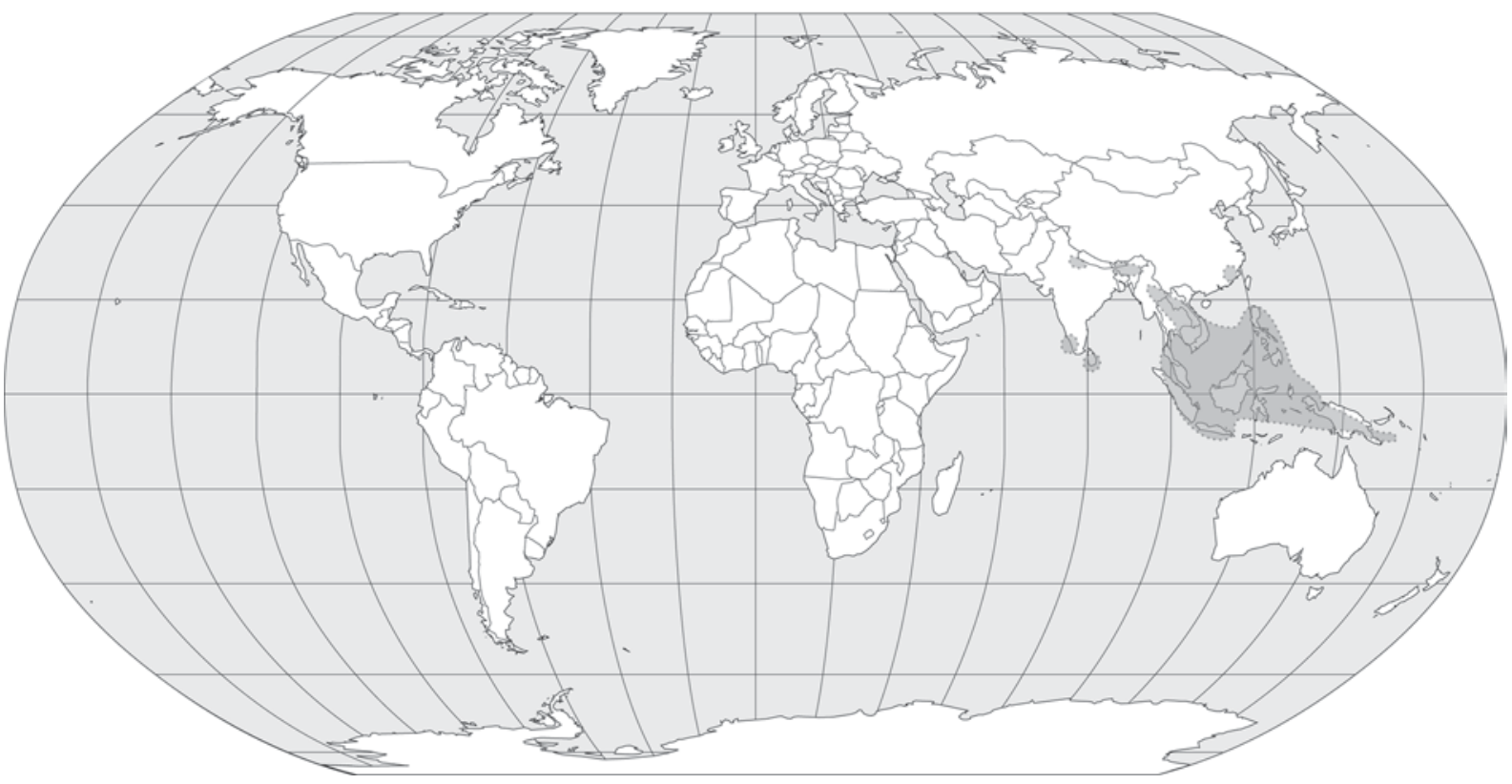

Map 7. Distribution of the tribe Taphini.

Карта 7. Ареал трибы Taphini.

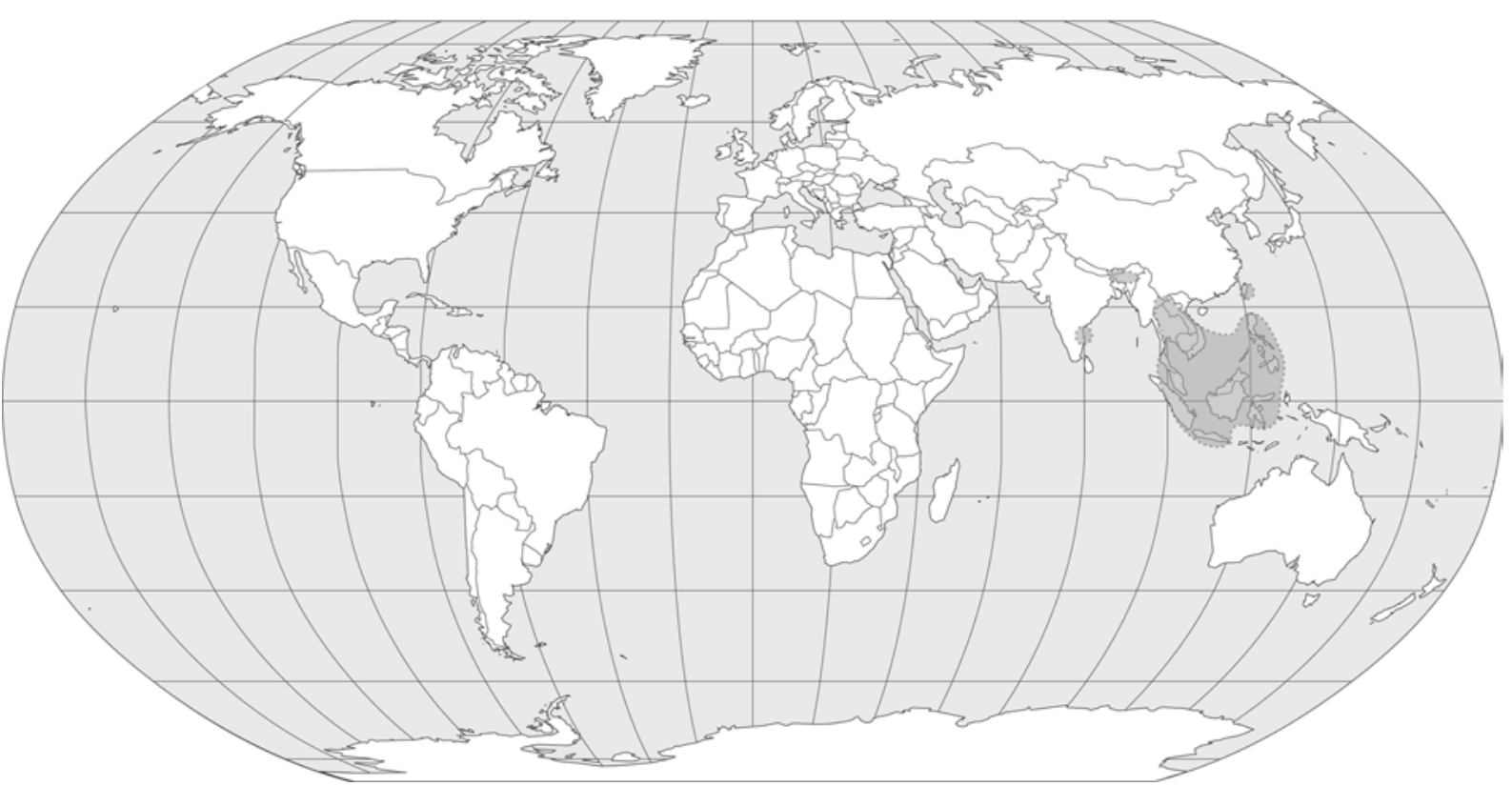

Map 8. Distribution of the tribe Lycoprogentini.

Карта 8. Ареал трибы Lycoprogentini. 
cal region, is still enigmatic. The current non-occurrence of the subfamily in South America is also difficult to explain. However, as the lycid fauna in the Neotropics remains poorly understood, it cannot be ruled out that future alpha-taxonomic and phylogenetic studies may still reveal relationships between dictyopterines and some South American Lycidae.

A list of Erotinae and Dictyopterinae is presented below. The Neotropical "Eros" taxa (E. antennalis
Kirsch, 1870, E. auratocollis Fauvel, 1861, E. crocatus Erichson, 1847, E. decoratus Erichson, 1847, E. melanopterus Lucas, 1857, E. melanurus Blanchard, 1843, E. patruelis Kirsch, 1873 and E. phaleratus Blanchard, 1843) are not included, as they were described when almost all not Lycus- or Calopteronlooking lycids were attributed to Eros and apparently belong in other subfamilies.

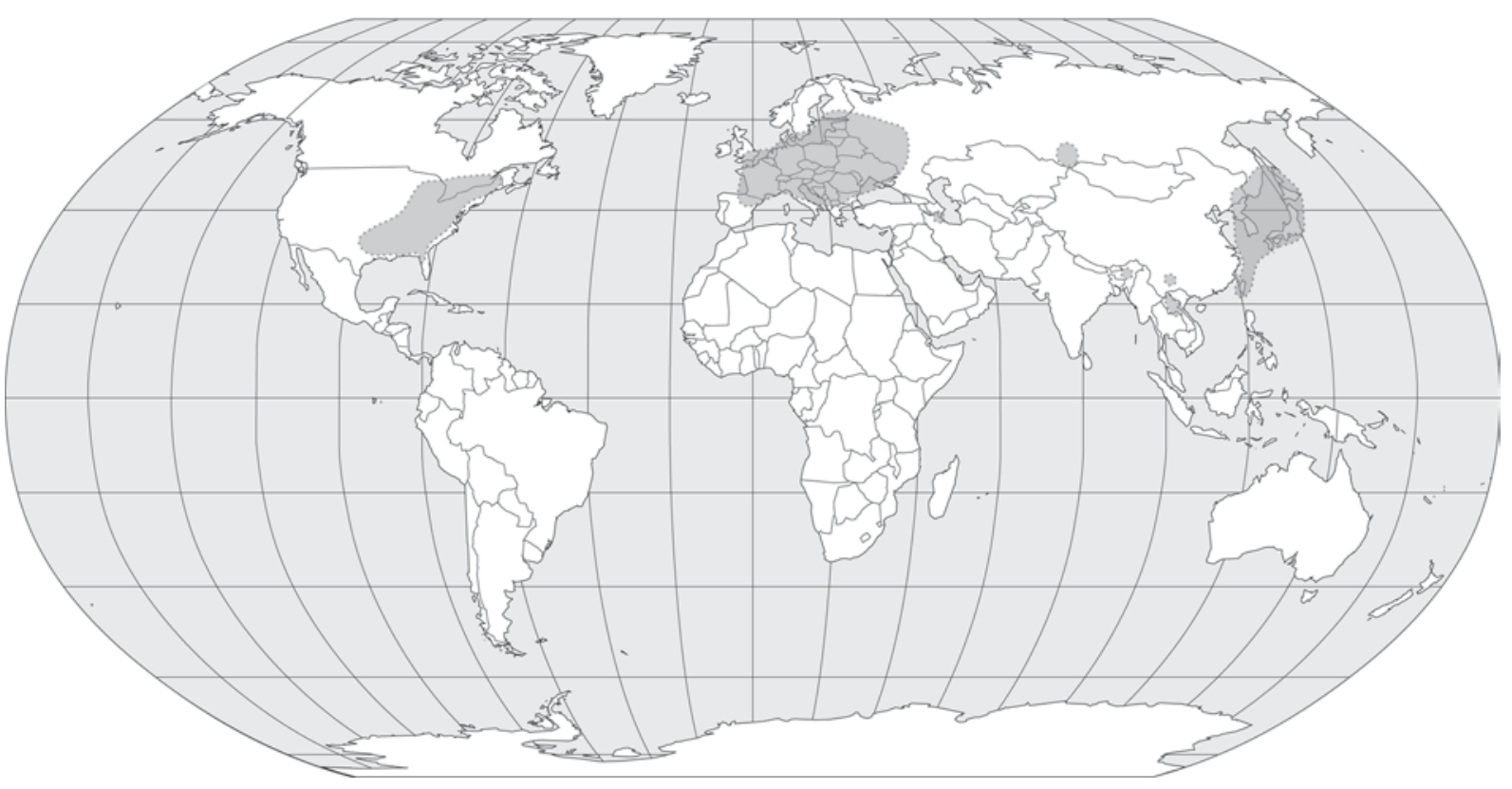

Map 9. Distribution of the subfamily Erotinae.

Карта 9. Ареал подсемейства Erotinae.

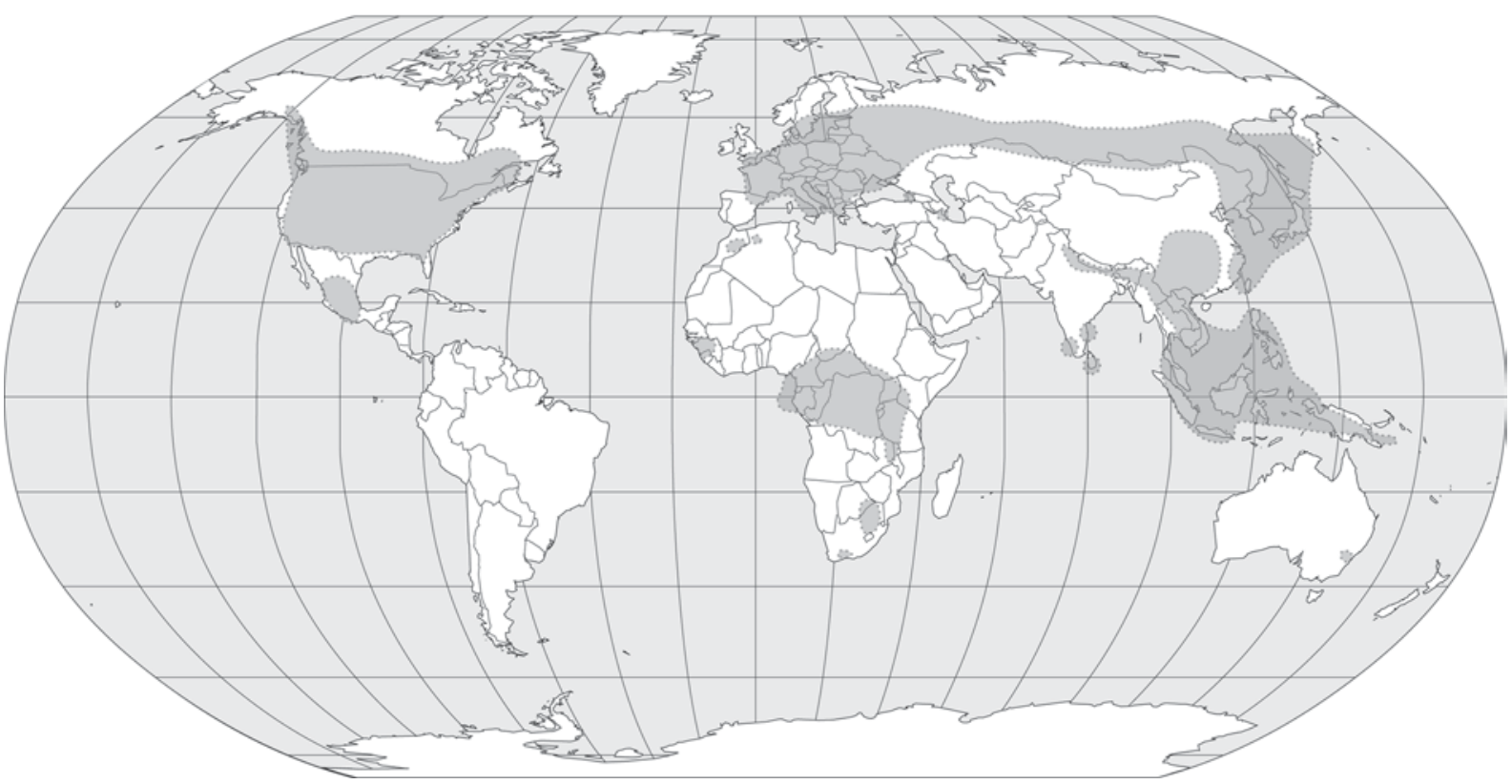

Map 10. Distribution of the subfamily Dictyopterinae. Карта 10. Ареал подсемейства Dictyopterinae. 


\section{A list of Erotinae and Dictyopterinae of the world}

Subfamily EROTINAE Leconte, 1881

type genus: Eros Newman, 1838

Tribe EROTINI Leconte, 1881

type genus: Eros Newman, 1838

Subtribe EROTINA Leconte, 1881

type genus: Eros Newman, 1838

Genus Eros Newman, 1838: 382

type species: Lycus humeralis Fabricius, 1801

humeralis Fabricius, 1801: 111 (Lycus). Eastern USA and Canada.

= obliquus Say, 1835: 156 (Omalisus)

= incestus Leconte, 1847: 78 (Eros)

Genus Erotides Waterhouse, 1879: 37

type species: Omalisus sculptilis Say, 1835

Subgenus Erotides (Erotides) Waterhouse, 1879: 37 type species: Omalisus sculptilis Say, 1835 sculptilis Say, 1835: 156 (Omalisus). E USA, SE Canada. = oblitus Newman, 1838: 382 (Eros)

= axillaris Melscheimer, 1846: 302 (Dictyopterus)

Subgenus Erotides (Glabroplatycis) Pic, 1914: 50

type species: Dictyopterus cosnardi Chevrolat, 1829 bocaki Matsuda, 2010: 87. China (Yunnan).

cosnardi Chevrolat, 1831: livr. 14: pl. 45 (Dictyopterus).

Central and western Europe, southern Scandinavia.

= flavescens $\mathrm{L}$. Redtenbacher, 1849: 319 (Dictyopterus)

= mercki Mulsant, 1838: 80 (Dictyopterus)

hayashii Matsuda, 2010: 91. Japan (Yaku-Shima Is.)

kanoi Nakane, 1967: 285 (Platycis). Taiwan.

lalashana Matsuda, 2010: 94. Taiwan.

nasuta Kiesenwetter, 1874: 255 (Eros). Centre of European part of Russia, South Siberia, FE Russia, Japan, Korea.

The distribution area is disjunctive, the gap between the western, or „Moscow“, patch and the western border of the eastern patch exceeds $3,000 \mathrm{~km}$.

= raddensis Pic, 1904: 25 (Platycis)

schneideri Kiesenwetter, 1878: 206 (Eros). Azerbaijan

(Talysh).

= abdominalis Reiche, 1878b: xxviii (Eros)

taiwana Kôno, 1932: 59 (Platycis). Taiwan.

Genus Konoplatycis Nakane, 1969: 155

type species: Platycis otome Kôno, 1832

matsudái Bocak, 1996: 1 (Platycis). China (Yunnan).

otome Kôno, 1932: 59 (Platycis). Japan.

Genus Platycides Kazantsev, 2012, gen.n.

type species: Platycides holzschuhi Kazantsev, 2012

holzschuhi Kazantsev, 2012, sp.n. Laos.

Genus Platycis Thomson, 1864: 162

type species: Pyrochroa minuta Fabricius, 1787 consobrina Bourgeois, 1902: 90. Japan.

formosomontana Matsuda, 2010: 112. Taiwan. minuta Fabricius, 1787: 163 (Pyrochroa). Europe, W Siberia.

The distribution of the species is probably disjunctive.

= pusilla Gmelin, 1790: 188 (Lampyris)

= sicula Pic, 1914: 50

Subtribe PSEUDAPLATOPTERINA Kazantsev, 2012, subtr.n.

type genus: Pseudaplatopterus Kleine, 1940

Genus Pseudaplatopterus Kleine, 1940: 179

type species: $P$. ascheelei Kleine, 1940
Subgenus Eropterus Green, 1951: 14

type species: Dictyopterus trilineatus Melsheimer, 1846

= Asioplateros Nakane, 1969: 9

type species: Asioplateros flavipennis Nakane, 1967 arculus Green, 1951: 17. E USA, SE Canada.

aritai Sato \& Ohbayashi, 1968: 66 (Aplatopterus). Japan. bilineatus Green, 1951: 17. E USA (Tennessee).

flavipennis Nakane, 1969: 9 (Asioplateros). Taiwan. glebulus Kazantsev, 2004: 31. Laos.

nothus Kiesenwetter, 1874: 58 (Eros). Japan.

ohkurai Matsuda, 1992: 94. Taiwan.

rectus Green, 1951: 16. E USA.

taiwanus Matsuda, 1992: 92. Taiwan.

trilineatus Melsheimer, 1846: 303 (Dictyopterus). E USA,

SE Canada.

yakushimaensis Ohbayashi, 1954: 22 (Plateros). Japan.

Subgenus Pseudaplatopterus Kleine, 1940: 179

type species: $P$. ascheelei Kleine, 1940

ascheelei Kleine, 1940: 179. Extinct. Baltic amber.

Tribe LOPHEROTINI Kazantsev, 2012, tr.n.

type genus: Lopheros Leconte, 1881

Genus Aplatopterus Reitter, 1911: 250

type species: Lycus rubens Gyllenhal, 1817

rubens Gyllenhal, 1817: 31 (Lycus). Europe, including

Scandinavia and central Russia, S Siberia.

= sanguinea Scopoli, 1763: 38 (Cassida) [homonym]

Genus Eulopheros Kazantsev, 1995: 41

type species: Eros harmandi Bourgeois, 1902

harmandi harmadi Bourgeois, 1902: 89 (Eros). FE Russia

(Sakhalin, Kurils), Japan.

= nakanei Winkler, 1952: 407 (Aplatopterus)

harmandi hiroshimensis Nakane, 1969: 109 (Lopheros).

Japan (Hiroshima).

harmandi shikokuanus Nakane, 1969: 110 (Lopheros). Japan (Shikoku).

Genus Lopheros Leconte, 1881: 23

type species: Omalisus fraternus Randall, 1838

= Falsoconderis Pic, 1926: 22

type species: Falsoconderis pubescens Pic, 1926

= Eudictyoptera Barovskij, 1930: 287

type species: Eudictyoptera brevicornis Barovskij, 1930

braeti Bourgeois, 1905: 46 (Dictyoptera). India (Bengal).

brevicornis Barovskij, 1930: 288 (Eudictyoptera). FE Russia (Primorskij Kraj).

= imanensis Medvedev, 1970: 165 (Aplatopterus)

brunneorubens Medvedev, 1966: 37 (Aplatopterus). FE

Russia (Kurils), Japan.

= konoi Nakane, 1969: 115

crassipalpis Nakane, 1969: 117. Japan

crenatus Germar, 1824: 61 (Homalisus). E USA, SE Canada.

= cruciatus Randall, 1838: 15 (Omalisus)

fraternus Randall, 1838: 15 (Omalisus). E USA.

lineatus Gorham, 1883: 406 (Plateros). Poland, FE Russia

(Primorskij Kraj, Amur), Japan (Honshu), NE China.

The distribution area is disjunctive, the gap between the western and eastern pockets exceeds $6,000 \mathrm{~km}$.

$=$ motschulskii Barovskij, 1930: 359 (Dictyoptera)

= mamaevi Medvedev, 1966: 36 (Aplatopterus)

mandshuricus Kleine, 1940: 112 (Eudictyoptera). NE China. minimus Nakane, 1969: 120. Japan.

pubescens Pic, 1926: 23 (Falsoconderis). Laos, Vietnam.

= apicicornis Pic, 1931: 97 (Falsoconderis)

septentrionalis Kôno, 1932: 58 (Aplatopterus). FE Russia

(Sakhalin, Kurils), Japan.

= japonicus Pic, 1942: 2 (Aplopterus) 
Genus Protolopheros Kazantsev, 2012: in press type species: Protolopheros hoffeinsorum Kazantsev, 2012 hoffeinsorum Kazantsev, 2012: in press. Extinct. Baltic amber.

Subfamily DICTYOPTERINAE Houlbert, 1922 type genus: Dictyoptera Latreille, 1829

Tribe DICTYOPTERINI Houlbert, 1922

type genus: Dictyoptera Latreille, 1829

Subtribe DICTYOPTERINA Houlbert, 1922

type genus: Dictyoptera Latreille, 1829

Genus Benibotarus Kôno, 1932: 56

type species: Eros spinicoxis Kiesenwetter, 1874

Subgenus Benibotarus (Benibotarus) Kôno, 1932: 32 type species: Eros spinicoxis Kiesenwetter, 1874

spinicoxis Kiesenwetter, 1874: 254 (Eros). FE Russia (Primorskij Kraj and Kurils), China (Shaanxi, Sichuan, Jiangxi, Guizhou, Taiwan), Japan.

= krivolutzkii Medvedev, 1966: 36 (Dictyoptera)

Subgenus Benibotarus (Sibetarus) Bocák \& Bocáková, 1991: 319

type species: Dictyopterus taygetanus Pic, 1905

alternatus Fairmaire, 1856: 531 (Dictyopterus). Spain

(Pyreneans), France (Pyreneans).

arnoldii Barovskij, 1932: 139 (Pyropterus). Azerbaijan (Talysh), Iran (Talysh).

longicornis Reiche, 1878: xxvii (Eros). S Russia (NW Caucasus), Georgia.

$=$ shelkovnikovi Barovskij, 1930: 65 (Pyropterus)

rubripes Pic, 1897: 220 (Pyropterus). Algeria, Morocco.

taygetanus Pic, 1905: 185 (Dictyopterus). Central and south-eastern Europe

= fiedleri Reitter, 1907: 25 (Dictyopterus)

Genus Chinotaphes Bocák \& Bocáková, 1999: 48 type species: C. weibaoshanensis Bocák \& Bocáková, 1999 hmong Kazantsev, 2006: 217. N Thailand.

weibaoshanensis Bocák et Bocáková, 1999: 48. China (Yunnan).

Genus Dictyoptera Latreille, 1829: 465 type species: Pyrochroa aurora Herbst, 1784 aurora Herbst, 1784: 105 (Pyrochroa). Europe, N Asia, North America $\mathrm{N}$ of Mexico.

= sanguineus Linnaeus, 1761: 202 Cantharis [homonym] = coccineus Linnaeus, 1767: 648 Cantharis [homonym] = coccinatus Say, 1835: 155 (Omalisus)

= hybridus Mannerheim, 1843: 88 (Eros)

= superba Motschulsky, 1860: 115

= nigripes Schaeffer, 1911: 121 (Eros)

elegans Nakane et Winkler, 1952: 133. Japan.

formosana Nakane, 1969: 217. Taiwan.

forticornis Pic, 1942: 1. China.

gansuensis Kazantsev, 2004: 25. China (Gansu).

gorhami Kôno, 1932: 57. Japan.

= erythropterus Gorham, 1883: 400 (Eros) (homonym)

laomontana Kazantsev, 2012, sp.n. Laos.

laosensis Pic, 1926: 23 (Conderis). Laos.

marginicollis Boheman, 1858: 73. China (Hong Kong).

panicola Kazantsev, 2012, sp.n. Laos.

phoupanensis Kazantsev, 2012, sp.n. Laos.

quadricostata Pic, 1927: 6 (Pyropterus). N Vietnam, Laos.

= bicoloricornis Pic, 1933: 110 (Pyropterus)

recticarinata Kazantsev, 2012, sp.n. Laos.

sapporensis Kôno, 1932: 57. FE Russia (Kurils), Japan.

= ohbayashii Nakane, 1969: 129

simplicipes Mannerheim, 1843: 245. W North America (from Alaska to Arizona).

= laeta Motschulsky, 1860: 115

speciosa Ohbayashi, 1954: 19. Japan.

triachroma Kazantsev, 2012, sp.n. Vietnam.

velata Gorham, 1883: 402 (Eros). FE Russia (Kurils), Japan.

= pseudovelata Medvedev, 1966: 36

Genus Greenarus Kazantsev, 1995: 40

type species: Eros thoracicus Randall, 1838

belokobylskii Kazantsev, 2004: 29 Vietnam.

nigripennis Nakane \& Ohbayshi, 1958: 80 (Benibotarus). Japan.

thoracicus Randall, 1838: 14 (Eros). USA, Canada.

= praefectus Newman, 1838: 382 (Eros)

Genus Helcophorus Fairmaire, 1891: 129

type species: H. miniatus Fairmaire, 1891

= Xylobanoides Kleine, 1929: 237

type species: Xylobanus unicolor Gorham, 1903

$=$ Hiekeolycus Winkler, 1987: 66

type species: Hiekeolycus berendti Winkler, 1987

angustatus Pic, 1929: 7 (Dictyopterus). N Vietnam.

berendti Winkler, 1987: 67 (Hiekeolycus). Extinct. Baltic amber.

brevilobus Bocáková, 1994 (Pyropterus). Kashmir. delicatus Kazantsev, 1996: 84. China (Hubei, Gansu). gobindanus Kazantsev, 2004: 28. N India (UP). miniatus Fairmaire, 1891: 129. Kashmir, Pakistan.

= unicolor Gorham, 1903: 324 (Xylobanus)

= miniata Pic, 1928: 267 (Dictyoptera)

murzini Kazantsev, 2004: 26. China (Yunnan).

ostindicus Kazantsev, 1996: 83. N India (Darjeeling).

tricolor Kazantsev, 2000. China (Sichuan, Yunnan).

Genus Kolibaceum Winkler, 1987: 62

type species: K. balticum Winkler, 1987

= Pietrzeniukia Winkler, 1987: 68

type species: P. kunowi Winkler, 1987

Subgenus Kolibaceum (Kolibaceum) Winkler, 1987: 62 type species: K. balticum Winkler, 1987 balticum Winkler, 1987: 63. Extinct. Baltic amber. = kunowi Winkler, 1987: 70 (Pietrzeniukia)

Subgenus Kolibaceum (Laterialis ) Kazantsev, 1990: 14 type species: Eros oculatus Gorham, 1886 oculata Gorham, 1886: 401 (Eros). Japan.

= diversicollis Pic, 1942: 2 (Pyropterus)

= sanguinipennis Nakane \& Ohbayashi, 1958: 80 (Benibotarus)

Subgenus Kolibaceum (Tricostaeptera) Kazantsev, 1997: 160

type species: Tricostaeptera sanguinea Kazantsev, 1997 sanguinea Kazantsev, 1997: 160. China (Hubei). tricostata Pic, 1927: 6 (Pyropterus). Vietnam. shirozui Nakane, 1968: 218 (Benibotarus). Taiwan.

Genus Parataphes Kleine, 1925b: 103

type species Parataphes dohertyi Kleine, 1925 dohertyi Kleine, 1925: 134. Burma. sanguinolentus Kleine, 1929: 237. India. nanus Kleine, 1939: 9. China, Burma.

Genus Propyropterus Nakane, 1968: 219

type species: $P$. pygidialis Nakane, 1968

Subgenus Propyropterus (Propyropterus) Nakane, 1968: 219

type species: $P$. pygidialis Nakane, 1968

kanoi Nakane, 1968: 222. Taiwan. 
plateroides Kazantsev, 2004: 32. Taiwan. pygidialis Nakane, 1968: 219. Taiwan.

\section{Subgenus Propyropterus (Paralopheros) Kazantsev, 1993: 64}

type species: Conderis diversipennis Pic, 1921

diversipennis Pic, 1921: 7 (Conderis). China (Yunnan). fukiensis Kleine, 1940: 91 (Pyropterus). China (Fujiang, Guangdong).

Genus Punicealis Kazantsev, 1990: 11 type species: P. medvedevi Kazantsev, 1990 barovskii Medvedev, 1966: 36 (Dictyoptera). FE Russia (Sakhalin and Kurils).

hamata Mannerheim, 1843: 245 (Eros). NW of North America (from Idaho and Washington to Alaska). martensi Kazantsev, 1993: 61. Nepal. medvedevi Kazantsev, 1990: 11. FE Russia (Primorskij

Kraj and Kurils), Japan.

= oculata Nakane, 1969: 125 (Dictyoptera) (homonym) miranda Barovskij, 1930: 360 (Dictyoptera). FE Russia (Primorskij Kraj).

munda Say, 1835: 155 (Omalisus). E USA (from Pennsylvania and Illinois to Georgia and Arizona).

Genus Pyropterus Mulsant, 1838: 81

type species: Lycus affinis Paykull, 1799 [Pyropterus nigroruber (Degeer, 1774)]

gilvus Kleine, 1928: 6. India (Himalaya). insularis Kazantsev, 1995: 35. FE Russia (Kurils), Japan. maritimus Kazantsev, 1995: 37. FE Russia (Primorskij Kraj). nigroruber Degeer, 1774: 46 (Lampyris). Europe, Siberia. = affinis Paykull, 1799: 176 (Lycus)

Genus Pyrotes Kazantsev, 2004: 21 type species Pyropterus sculpturatus C.O. Waterhouse, 1878 sculpturatus C.O. Waterhouse, 1878: 112 (Pyropterus). Borneo, Java, Singapore.

Genus Taphomimus Kazantsev, 1996: 400 type species: Taphomimus sarawakanus Kazantsev, 1996 diocisus Bocák \& Bocáková, 1991: 318 (Pyropterus). Vietnam. nanensis Kazantsev, 2004: 23. Thailand. sarawakanus Kazantsev, 1996: 401. Borneo. huaphanensis Kazantsev, 2012, sp.n. Laos. tonkineus Pic, 1923: 16 (Taphes). Vietnam.

Subtribe FLAGRAXINA Kazantsev, 2004 type genus: Flagrax Kazantsev, 1992

Genus Flagrax Kazantsev, 1992: 38

type species: Stadenus auberti Bourgeois, 1881 atripes Pic, 1922: 6 (Stadenus). S Africa. auberti auberti Bourgeois, 1881: xxxvii (Stadenus). Tropical Africa.

= angustatus Pic, 1946: 5 (Stadenus)

= antennalis Bourgeois, 1889: 246 (Stadenus)

= atricollis Pic, 1915: 13 (Stadenus)

= breveapicalis Pic, 1946: 5 (Stadenus)

= innotatus Pic, 1928: 61 (Stadenus)

= leonensis Pic, 1946: 5 (Stadenus)

= mocquerysi Pic, 1915: 13 (Stadenus)

= geniculatus Pic, 1915: 14 (Stadenus)

= notaticollis Pic, 1946: 5 (Stadenus)

= rufifrons Pic, 1915: 13 (Stadenus)

auberti semifulvus Fairmaire, 1891: 116 (Stadenus). Biafra

Gulf (St. Tome Is.).

= nodieri Pic, 1946: 6 (Stadenus)

bifoveolatus Pic, 1924: 161 (Stadenus). Biafra Gulf. bolivari Bourgeois, 1905: 193 (Stadenus). W Africa. grandis Kleine, 1942: 4 (Stadenus). Zaire. laticornis Pic, 1946: 5 (Stadenus). W Africa. parallelus Pic, 1922: 6 (Stadenus). W Africa. = bicoloripes Pic, 1946: 5 (Stadenus) subelongatus Pic, 1915: 13 (Stadenus). W Africa.

=lamottei Pic, 1958: 160 (Stadenus)

Genus Phaneros Kazantsev, 1992: 42 type species: Stadenus xanthopterus Bourgeois, 1908

Subgenus Phaneros (Phaneros) Kazantsev, 1992: 42

type species: Stadenus xanthopterus Bourgeois, 1908 caffer Kleine, 1933: 4 (Stadenus). SE Africa (Lake Nyassa). costatus Pic, 1915: 12 (Stadenus). Cameroon. inapicalis Pic, 1928: 61 (Stadenus). Uganda, Zaire.

= incrassicornis Pic, 1946: 6 (Stadenus) nigricollis Pic, 1946: 6 (Stadenus). Zaire. xanthopterus Bourgeois, 1908: 274 (Stadenus). E Africa (Kenya, Tanzania)

Subgenus Phaneros (Bourgeoisiella) Kazantsev, 1992: 44

type species: Stadenus ruficeps Bourgeois, 1910 ruficeps (Bourgeois, 1910: 117 (Stadenus). Kenya, Tanzania. = sjoestedti Bourgeois 1910: 118 (Stadenus)

Genus Phaneros (Kleineria) Kazantsev, 2004: 35 type species: Kleinella pudica Kazantsev, 1992 = Kleinella Kazantsev, 1992: 44 (homonym) type species: Kleinella pudica Kazantsev, 1992 pudica Kazantsev, 1992: 44 (Kleinella). Tanzania. silvicola Kazantsev, 2006: 63. S Africa (Transvaal).

Genus Staepteron Kazantsev, 1992: 50 type species: Calopteron cyanoxanthum Bourgeois, 1884 cyanoxanthum 1908: 274 (Calopteron). S Africa (W Cape).

Tribe TAPHINI Bocák et Bocáková, 1990

type genus: Taphes C.O. Waterhouse, 1878

Genus Coloberos Bourgeois, 1885: 82

type species Coloberos tenellus Bourgeois, 1885 apicalis Pic, 1911: 165. Moluccas (Obi Is.). atricollis Pic, 1928: 17. Sumatra. bicolor Bocák \& Bocáková, 1991: 13. N Guinea. borneensis Pic, 1942: 4. Borneo. costatus Pic, 1922: 13. Java. incisus Pic, 1925: 6 (Pyropterus). Java. irregularis Pic, 1942: 4. Indochina (Cochinchine). klossi Blaire, 1928: 179 (Pyropterus). Sumatra. longipennis Pic, 1911: 331. Ceylon. malaccanus Pic, 1922: 13 (Pyropterus). Malaysia. multiareolatus Pic, 1911: 265. Nias. pahanganus Kleine, 1939: 366 (Pyropterus). Malaysia. particularis Pic, 1928: 17. Java. robusticornis Pic, 1928: 17. India (Cochin). rufithorax Kleine, 1933: 13 (Pyropterus). Moluccas. simplex Pic, 1928: 17. Java. tenellus Bourgeois, 1885: 83. Sikkim. tener Kleine, 1928: 83. Borneo. testaceipennis Pic, 1928: 17. Patria? vicinus Pic, 1928: 17. Banguey. woodlarkianus Montrouzier, 1855 (Dictyoptera). Murua Is. ("Woodlark").

Genus Taphes C.O. Waterhouse, 1878: 102 type species Taphes brevicollis C.O. Waterhouse, 1878 acceptus Kleine, 1926: 101 Philippines. boucardi Pic, 1928: 17 Sumatra. 
brevicollis C.O. Waterhouse, 1878: 111 India, Indochina, Malay Peninsula, Sunda Islands.

frontalis C.O. Waterhouse, 1878: 111 Malay Peninsula, Sunda Islands.

modiglianii Pic, 1922: 13 Sumatra.

Tribe LYCOPROGENTINI Bocák et Bocáková, 2008

type genus: Lycoprogentes Pic, 1915

Genus Lycoprogentes Pic, 1915: 6

type species Lycoprogentes puilloni Pic, 1915 = Lycoprogenthes Pic: Bocák \& Bocáková, 1990; Bocáková \&

Bocák, 2007; Bocák \& Bocáková, 2008 (lapsus calami)

type species Lycoprogenthes puilloni Pic, 1915

= Parapyropterus Kleine, 1926: 104

type species Parapyropterus nigrostriatus Kleine, 1926

= Protaphes Kleine, 1926: 363

type species Protaphes confertus Kleine, 1926

= Pseudosynchonnus Pic, 1922: 104

type species Pseudosynchonnus testaceus Pic, 1922

apicalis Pic, 1922: 13 (Pseudosynchonnus). Borneo.

areolatus Kleine, 1926: 281 (Protaphes). Sumatra.

arrogans Kleine, 1926: 365 (Protaphes). Borneo.

celebensis Kleine, 1933: 2 (Protaphes). Celebes.

confertus Kleine, 1926: 364 (Protaphes). Borneo.

confirmatus Kleine, 1926: 365 (Protaphes). Borneo.

corporaali Pic, 1925: 6 (Pseudosynchonnus). Sumatra.

costatus Pic, 1922: 13 (Pseudosynchonnus). Borneo.

croceus Kleine, 1943: 143 (Protaphes). India (Madras).

drescheri Kleine, 1931: 250 (Protaphes). Java.

himalejicus Bourgeois, 1882: cxliv (Pyropterus). Sikkim.

incarnatus Kleine, 1931: 251 (Protaphes). Java.

minutus Kleine, 1930: 95 (Protaphes). Perak.

monticola Kleine, 1939: 8 (Protaphes). Burma.

nigronitens Kleine, 1938: 366 (Protaphes). Pahang.

nigrostriatus Kleine, 1926: 104 (Parapyropterus). Taiwan.

= bistriatus Kleine, 1943: 148 (Protaphes)

obliteratus Pic, 1925: 6 (Pseudosynchonnus). Sumatra.

provincialis Kleine, 1939: 9 (Protaphes). Burma

puilloni Pic, 1915: 6. N India (Darjeeling).

remissus Kleine, 1933: 2 (Protaphes). Sangi Is

testaceus Pic, 1922: 13 (Pseudosynchonnus). Malay Peninsula. transversesignatus Kleine, 1933: 3 (Protaphes). Java.

Tribe PROTEROTAPHINI Kazantsev, 2012, tr.n.

type genus: Proterotaphes Kazantsev, 2006

Genus Proterotaphes Kazantsev, 2006: 218

type species: Proteros sempiternus Kazantsev, 2004

= Proteros Kazantsev, 2004: 18 (homonym)

type species: Proteros sempiternus Kazantsev, 2004

sempiternus Kazantsev, 2004: 19 (Proteros). Australia

(New South Wales)

Tribe MACROLYCINELLINI Kazantsev, 2012, tr.n.

type genus: Macrolycinella Pic, 1922

Genus Macrolycinella Pic, 1922: 21

type species: Macrolycinella bicolor Pic, 1922

bicolor Pic, 1922: 21. Mexico.

bicoloricollis Kazantsev, 2010: 280. Mexico.

bicoloripennis Kazantsev, 2010: 280. Mexico.

dichroma Kazantsev, 2010: 280. Mexico.

ACKNOWLEDGEMENTS. I wish to express my sincere gratitude to Dr. J. Menier (Muséum national d'Histoire naturelle, Paris) through whose courtesy I was able to study the MNHN Lycidae collections under his care and to Dr. C. Holzschuh (Villah, Austria) for the new interesting lycid material from Laos. My special thanks are due to Prof. K.V. Makarov (Moscow) for his kind help with the colour photos of the new species.

\section{References}

Bocák L., Bocáková M. 1990. Revision of the suprageneric classification of the family Lycidae (Coleoptera) // Polskie Pismo Entomologiczne. Vol.59. P.623-676.

Bocák L., Bocáková M. 1991. Notes on some Palaearctic and Oriental representatives of the tribe Erotini (Coleoptera, Lycidae) // Acta Entomologica Bohemoslovaca. Vol.88. P.313-326.

Bocák L., Bocáková M. 1999. New taxa of Lycidae from Indonesia, China and Nepal (Coleoptera) // Acta Universitatis Palackianae Olomucensis, Biol. T.37. P.47-56.

Bocák L., Bocáková M. 2008. Phylogeny and classification of the family Lycidae (Insecta: Coleoptera)// Annales Zoologici. Vol.58. No.4. P.695-720.

Bocáková M., Bocák L. 2007. Lycidae // Löbl I. \& Smetana A. (eds.). Catalogue of Palaearctic Coleoptera. Vol.4. Stenstrup: Apollo Books. P.211-224

Cicero J.M. 1994. Composite, Haustellate Mouthparts in Netwinged Beetles and Firefly Larvae (Coleoptera, Cantharoidea: Lycidae, Lampyridae) // Journal of Morphology. Vol.219: 183-192.

Crowson R.A. 1981. The Biology of the Coleoptera. London: Academic Press. 802 p.

Kazantsev S.V. 1990. Two new subgenera and one new species of the genus Dictyoptera (Coleoptera, Lycidae) from Eastern Asia // Vestnik Zoologii. Vol.1. P.10-15 [in Russian with English summary].

Kazantsev S.V. 1992. Revision of the genus Stadenus (Coleoptera, Lycidae) of Africa // Russian Entomological Journal. Vol.1. No.1. P.37-50.

Kazantsev S.V. 1993. Lycides nouveaux ou peu connus de l'Indochine (Coleoptera) // Bulletin du Muséum National d'Histoire naturelle, Paris, $4^{\mathrm{e}}$ sér. Vol.15. Section A(1-4). P.49-68.

Kazantsev S.V. 1995. New data on the Russian fauna of Lycidae (Coleoptera) // Zoologicheskij Zhurnal. Vol.74. No.5. P.35-44 [in Russian with English summary].

Kazantsev S.V. 1996a. New taxa of Erotini (Insecta: Coleoptera: Lycidae) from Borneo // Raffles Bulletin of Zoology. Vol.44. No.2. P.399-403.

Kazantsev S.V. 1996b. A review of Pyropterus subgen. Helcophorus Fairmaire with the description of two new oriental species (Lycidae, Coleoptera) // Elytron. Vol.10. P.81-88.

Kazantsev S.V. 1997. A recent species of the fossil genus Kolibaceum Winkler (Coleoptera, Lycidae) from Eastern China // Entomologica Basiliensia. Vol.20. P.159-164.

Kazantsev S.V. 2000. New and little known African lycids (Coleoptera) // Russian Entomological Journal. Vol.9. No.3. P.241-248.

Kazantsev S.V. 2004. Phylogeny of the tribe Erotini (Coleoptera, Lycidae), with descriptions of new taxa // Zootaxa. Vol 496. P.1-48.

Kazantsev S.V. 2005. Morphology of Lycidae with some considerations on evolution of the Coleoptera // Elytron. Vol.17-18 (2004) et Coleopterological Monographs. Vol.3. P.73-248.

Kazantsev S.V. 2006. A review and phylogenetic analysis of Afrotropical Dictyopterini (Coleoptera, Lycidae) // Mitteilungen aus dem Museum für Naturkunde in Berlin, Deutsche Entomologische Zeitschrift. B.53. H.1. S.43-64.

Kazantsev S.V. 2010. On the status and systematic position of the genera Falsolucidota Pic, 1921 and Macrolycinella Pic, 1922, with notes on Lopheros LeConte, 1881 (Lycidae, Coleoptera) // Russian Entomological Journal. Vol.18. No.4 (2009). P.277-283.

Kazantsev S.V. 2012a. An annotated checklist of Cantharoidea (Coleoptera) of Russia and adjacent territories // Russian Entomological Journal. Vol.20. No.4 (2011). P.387-410.

Kazantsev S.V. 2012b. A review of the amber Lycidae (Insecta: Coleoptera), with description of a new genus // Zootaxa. In press

Kleine R. 1929. Neue Indische Lycidae nebst faunistischen Bemerkungen // Indian Forest Records. Vol.13. No.6 (1928). P.221-268. 5 Tbs.

Kleine R. 1933. Pars 123: Lycidae// Coleopterorum Catalogus auspiciis et auxilio W. Junk editus a Schenkling. Berlin: W. Junk. 145 p.

LeConte J.L. 1881. Synopsis of the Lampyridae of the United States // Transactions of the American Entomological Society. Vol.9. P.15-72.

Matsuda K. 2010. Revision of the Platycis-group (Coleoptera: Lycidae) from the Holarctic region // Entomological Review of Japan. Vol.65. No.1. P.75-126.

Miller R.S. 2002. Family 59. Lycidae Laporte, 1838 // Arnett R.H., Jr., Thomas M.C., Skelley P.E. \& Frank J.H. (eds.). American Beetles. Vol.2. Polyphaga through Curculionoidea. Boca Raton, FL: CRC Press. P. 174-178 